\title{
O mar e a poesía galega. Singraduras na construcción da patria da lingua
}

\author{
Francisco Fernández Rei \\ Instituto da Lingua Galega. \\ Universidade de Santiago de Compostela
}

\author{
A meus pais, vivas testemuñas \\ dunha Galicia mariñeira en devalo. \\ Ás mariscadoras e ós mariñeiros \\ que coas súas mans salvaron as rías \\ cando o mar choraba bágoas negras.
}

\begin{abstract}
Resumo:
Neste artigo estúdiase a presencia do mar e do léxico relacionado co mar na poesía galega. Despois dunha breves consideracións sobre o mar na lírica galega medieval, fanse calas no vocabulario marítimo da poesía de Pondal, Manuel Antonio, Avilés de Taramancos e outros autores contemporáneos. O obxectivo fundamental é ver como se foi introducindo e propagando no galego literario moderno diverso léxico do mar, popular e culto, que hoxe forma parte do galego común nos seus diversos rexistros.
\end{abstract}

\section{Palabras chave:}

Lingua galega - estandardización - poesía galega - vocabulario marítimo

\begin{abstract}
:
This article considers the presence of the sea and maritime vocabulary in Galician poetry. After brief considerations of the sea in medieval Galician poetry, special attention is paid to the maritime content in the poetry of Pondal, Manuel Antonio, Avilés de Taramancos and other $20^{\text {th }}$ century writers, with reference to the most recent maritime poetry. The fundamental aim is to analyse the introduction and the diffusion into modern literary Galician of a number of terms that are currently used in the different linguistic registers.
\end{abstract}

Key words:

Galician language - standardization - Galician poetry - maritime vocabulary.

Este artigo é o resultado de mergullarse a bucío no mar da poesía galega, de onte e de hoxe, para tratar de ver como se foron introducindo e propagando no galego escrito termos relacionados co mar, populares e cultos. Moito dese léxico hoxe xa forma parte da patria da lingua dos galegofalantes, ben na acepción mariñeira, ben noutras acepcións por ampliación semántica, como ocorreu con formas populares 
como ronsel ou laño. Outras veces son formas cultas como áncora ou rocha, moi usadas na lingua literaria, en concorrencia coas populares risón ${ }^{1}$, que é un tipo de áncora, e cón (ou pena).

Despois dunhas notas sobre o mar medieval e o seu ronsel na poesía moderna, fanse mergullos no léxico do mar en 110 anos de tradición literaria, dos Queixumes dos pinos de Pondal, de 1886, a Contra Mar de Xesús Franco e Fascinio de Chus Pato, poemarios de 1995. Ademais destas obras, fanse calas no vocabulario relacionado co mar na poesía de Leiras Pulpeiro, Cabanillas, Manuel Antonio, BouzaBrey, Cunqueiro, Zapata García, Cuña Novás, Bernardino Graña, Méndez Ferrín, Xohana Torres, Avilés de Taramancos e Luísa Castro. E no final da singradura fanse referencias a diversos poemarios con sal e mar moi recentes, e en especial á obra de Alexandre Nerium.

O artigo é, fundamentalmente, unha ampliación do mar na poesía galega que analicei en dous traballos, un édito (Fernández Rei 2000) e outro inédito (Fernández Rei 2003a). Inclúo novos autores e reviso algunhas documentacións do galego escrito presentadas en Fernández Rei (1999), unhas veces retrasando primeiras documentacións, e outras completando a documentación existente na Base de Datos Lexicográfica do ILG² (en adiante Base-ILG) por ter consultado obras con mar dos anos 70 e 80 do séc. XX e outras dos últimos anos que aínda non foron lematizadas e concordadas nesa Base-ILG.

\section{O mar da poesía medieval}

Mar, ondas e navíos forman parte da paisaxe de diferentes cantigas de amigo medievais, á vez que o mar está presente noutras composicións poéticas galegoportuguesas". Segundo Tavani (1989: s. p.) na poesía galega medieval son "sobre todo as augas do mar as que asumen para a namorada un aspecto hostil, contrario

1 No Vocabulario ortográfico da lingua galega (Versión provisional) (1989) do Instituto da Lingua Galega e a Real Academia Galega a forma codificada é rizón; pero tendo en conta que nos portos galegos, tanto seseantes como non seseantes, a áncora pequena de catro brazos (fateixa en portugués) ten como denominación xeral risón (Alvar 2, 1985: 1002) e que risón é a forma do galego eo-naviego (Barriuso 2002: 128), como o é de toda a costa de Asturias, das Figueiras-Castropol a Llanes, considero que a forma do galego estándar debería ser risón e non o moi probable castelanismo rizón.

2 A Base-ILG en abril do 2003 contaba con algo máis de 1.000 obras concordadas e lematizadas, cuns doce millóns de rexistros. Son textos literarios, ensaísticos e científicos en lingua galega desde os Séculos Escuros á actualidade, xunto con diversas escolmas de textos orais, a maior parte recollidos in situ por investigadores do ILG, moitos deles aínda inéditos.

3 Filgueira Valverde (1927) estudiou a paisaxe no Cancioneiro da Vaticana e Cotarelo Valledor (1970) analizou a presencia do mar neste mesmo Cancioneiro, mentres que Guerra da Cal (1958) glosou o tema do mar na nosa lírica medieval. 
á relación amorosa", á vez que considera que o mar é elemento separador por definición e "é sempre o inimigo, o rival co que a rapaza tenta competir en balde".

\subsection{As ondas e as ribeiras}

En Roi Fernández de Santiago hai ondas e altas ribas. Atrapada entre esas ondas e os esgrevios cantís da costa, "a velida non ten escapatoria, a súa tristeira sorte levanta vagas de amargura que afogan o corazón do poeta aínda antes de que as ondas do mar selen o destino da fremosa", como sinalou Tavani (1989: s. p. $)^{4}$

Quand'eu vejo las ondas
e las muit'altas ribas,
logo mi veen ondas
al cor pola velida:
maldito seja'l mare,
que mi faz tanto male!
$\quad(. .$.
Se eu vejo las ondas
e vejo las costeiras,
logo mi veen ondas
al cor pola ben feita:
maldito seja'l mare,
que mi faz tanto male!

A namorada da fermosísima cantiga de Mendinho ve angustiada como as ondas grandes do mar cercan a illa de S. Simón, "a illa da morte de amor máis fermosa do mundo" para Anxo Angueira, a illa onde estiveron moitos presos da guerra civil de 1936. A amiga non sabe remar e non aparece o barqueiro e remador que a poida zafar dunha case segura morte nese mar maior (e alto mar). Segundo Tavani (1989 s. p.), nesta xoia poética, exprésase "cunha parsimonia torturante a soidade da dona que (abandonada de todos) contempla con anguriada lucidez a progresión das ondas, que grandes son, e que a asulagarán ineluctablemente, e sen embargo ela pregúntase, ata o final, se o amigo virá salvala":

Sedia-m'eu na ermida de San Simion e cercaron-mi as ondas, que grandes son.

Eu atendend'o meu amigo. E verrá?

Estando na ermida ant'o altar, cercaron-mi as ondas grandes do mar.

Eu atendend'o meu amigo. E verrá? (...)

4 O texto desta cantiga e o das de Mendinho e Martín Códax están tirados de Tavani (1989). 
No ei barqueiro, nen remador:

morrerei fremosa no mar maior.

Eu atendend'o meu amigo. E verrá?

Non ei barqueiro, nen sei remar:

morrerei fremosa no alto mar.

Eu atendend'o meu amigo. E verrá?

As ondas e o mar levado (e o mar salido) de Vigo bañan as sete cantigas de Martín Códax. Para Tavani (1989: s. p.) o mar destas cantigas é unha divindade masculina adversa e violenta, que se pode identificar co rei, "que a dona de Martin Codax tenta exorcizar, subdivíndoo nos seus compoñentes femininos, as ondas":

Ondas do mar de Vigo,

se vistes meu amigo?

E, ai Deus, se verrá cedo!

Ondas do mar levado, se vistes meu amado?

E, ai Deus, se verrá cedo!

(...)

Estas cantigas coas ondas e illas do mar de Vigo tratan "da interminable historia do amor e reúnen fragmentos de múltiples historias eróticas recollidas das voces múltiples das vellas cantadeiras" (Blanco 1998: 83), que na literatura galega de finais do séc. XX están presentes en textos poéticos de diferentes autores.

Nunha das cantigas de romaría de Johan de Cangas a amiga suspira polo seu namorado nas ribeiras do mar. E nas moi fermosas mariñas de Johan Zorro a paisaxe é a ribeyra do rio (e do rio salido) e a ribeyra do alto.

\subsection{As barcas e os navios}

En Nuno Fernández Torneol a amiga ve andar barcas eno mar. En Johan Zorro hai barcas que o rei mete "no rio forte" e barcas que andan polo río, mais tamén hai as barcas desta coñecida mariña $a^{5}$ :

En Lixboa sôbre lo mar barcas novas mandey lavrar. ay mya senhor velida!

\footnotetext{
5 O texto está tirado de Brea (1996, II: 572).
} 


\begin{abstract}
En Lixboa sôbre lo lez barcas novas mandey fazer, ay mya senhor velida!

Barcas novas mandey lavrar e no mar as mandey deytar, ay mya senhor velida!

Barcas novas mandey fazer e no mar as mandey meter, ay mya senhor velida!
\end{abstract}

E nunha non menos coñecida mariña de Pai Gomez Charinho as flores do amigo van no poético navío e no popular barco, denominación xenérica do galego moderno para as embarcacións do mar e as barcas do río ${ }^{6}$ :

As ffroles do meu amigo
briosas van no navyo.
E vanss'as frores
d'aquí ben con meus amores,
idas som as frores
d'aquí ben con meus amores.

As ffrores do meu amado briosas van no barco.

$E$ vanss'as frores

d'aquí ben con meus amores, idas som as frores

d'aquí ben con meus amores. (...)

O mar protagoniza o sirventés de Gonçal'Eanes do Vinhal sobre a viaxe de Pero d'Ambroa a Ultramar, se cadra en compañía de María Balteira. Nesta viaxe, celebrada "com galhofa e até contestada por muitos, Pero d'Ambroa não teria ido mais além de Mompilher, no sul de França, com medo das tormentas do mar" (Lapa 1970: 268).

Na primeira estrofa aparece o mar e estados do mar (bon tempo, mao [tempo] e bõaça, o tempo calmo e sen vento) e no verso final das tres estrofas do sirventés está o sintagma tormenta de mar. Na segunda estrofa, aquí reproducida, figuran as formas mariñeiras nave, mar, frota e sota (parte baixa do barco):

\footnotetext{
6 O texto está tirado de Brea (1996, II: 711-712).
} 
E des i, já pola nave quebrar, aquí non dades vós ren polo mar come os outros que i van enton; poren tẽẽ que tamanho perdon non avedes come os que na frota van, e se deitan, con medo, na sota, sol que entenden tormenta do mar.

E na terceira estrofa, ademais de mar, hai dous animais mariños, un peixe escualiforme (o caçon) e un crustáceo decápodo (o lobaganto):

E nunca oímos doutr'ome falar que non temesse mal tempo do mar; e poren cuidan quantos aquí son que vossa madre con algun caçon vos fez, sen falha, ou con lobaganto; e todos esto cuidamos, por quanto non dades ren por tormenta do mar.

Na cantiga moral "Non me posso pagar tanto" de Afonso X, onde o rei con sinceridade, "que não exclui uma atitude de auto-ironia, confessa o seu repúdio pela guerra, o seu gosto do mar e o seu amor da aventura pacífica e lucrativa" (Lapa 1970: 13), hai dúas embarcacións, o galeon co que querería fuxir ("que mi alongue muit' aginha/ deste demo da campinha/ u os alacrães son") e o dormon, co que o rei querería ir comerciar pola marinha, pola beiramar:

E juro par Deus lo santo

que manto

non tragerei nen granhon

nen terrei d'amor razon

nen d'armas, por que quebranto

e chanto

ven delas toda sazon;

mais tragerei un dormon,

e irei pela marinha

vendend' azeit' e farinha;

e fugirei do poçon

do alacran, ca eu non

lhi sei outra meezinha.

(...)

ca mais me pago do mar

que de seer cavaleiro;

ca eu foi já marinheiro

e quero-m'ôi-mais guardar

do alacran, e tornar

ao que me foi primeiro. 
O dormon desta cantiga de Afonso X pode ser un helenismo, drómon 'navío de carga'; pero tamén podería tratarse, segundo Lapa (1970: 14) de "uma forma dornon, aumentativo de dorno ou dorna, forma esta ainda usual em galego, com o significado de "embarcação pequena".

\subsection{O ronsel do mar medieval: a mareta de Mendinho e Martín Códax}

Á obra de Cunqueiro, Luz Pozo Garza, Darío Xohán Cabana e moitos outros poetas do séc. XX chegan versos e referencias dos trobadores do mar de Vigo. É o ronsel do mar medieval, ese fío de auga que vai deixando o barco pola popa do barco, como din os mariñeiros de Rianxo; pero ás veces máis ben parece estarmos ante unha simple mareta, termo tamén da xente do mar da Arousa (e de Manuel Antonio), esas ondiñas que produce o barco e que van chegando cara á costa cada vez máis febles.

No poema "En Vigo, no sagrado", primeiro do poemario Concerto de outono (1981), Luz Pozo Garza (Ribadeo 1922) poetiza o amor a xeito de cantiga medieval nesas augas da badía viguesa, recreando Códax e Mendinho e tamén Fernandes Torneol:

En Vigo no sagrado navegar da badía as ondas non me furten o amor en Vigo navegar mar maior no segredo e tería que chorar na friaxe da ausencia polo amigo.

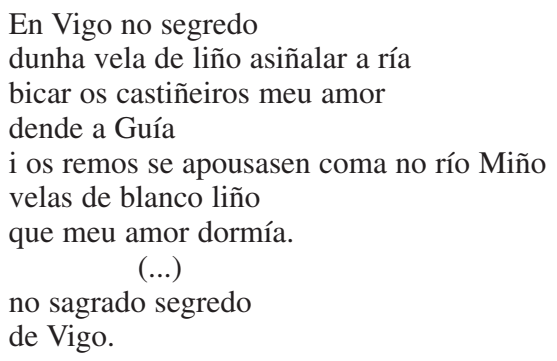

E no Códice Calixtino (1986), na "Cantiga para ler en tempo de penumbra” Luz Pozo reproduce e adapta ó galego actual versos de cantigas de Martín Códax:

Axiña pasa o tempo da total transparencia as verbas que deslizan un tránsito de soles ondas do mar levado unhas mans que circundan como un stradivarius os labios e a cintura nese momento a sombra perdeuse para sempre:

E ai Deus se virá cedo! (...) 
En Bernardino Graña hai algunha referencia ó mar sagrado de Martín Codax, no final do poema "Irei a Darbo" de Se o noso amor e os peixes Sar arriba andasen (1980):

Cheirarei erbas puras. Limpareime de vós, alá, en Liméns, no mar sagrado.

As mesmas ondas e o mesmo mar de Vigo aparecen nalgún dos sonetos de Patria do mar (1989) de Darío Xohán Cabana (Cospeito-Terra Cha 1952). "Ondas do mar de Vigo..." é o título dunha composición que se repite no verso inicial de cada estrofa do soneto que nos leva ó medievo, a Martín Códax. Nese poemario Darío canta noutro soneto as "Casitérides", illas da boca da ría de Vigo onde "achaban os antigos comerciantes/ despois de ter mil mares mareado,/ un porto contra os ventos ben gardado". Esas illas -que salvaron a ría do piche da marea negra do Prestige a finais do 2002- e as medievais ondas aparecen en "Illas Cíes" de Prometo a flor de loto (1992), de Luz Pozo:

Nas Cíes descubrimos a pericia das aves

e a medida celeste onde reside a luz

Bañámonos nas ondas

a compartir sulagos con dóciles palmípedas

e cunchiñas de nacre

$$
\text { (...) }
$$

No poema "Contrabando de amigo" de Antón Reixa (Vigo 1957), de Viva Galicia Beibe (1994), a namorada da cantiga de Mendinho segue "atendendo seu amigo" nesa illa de San Simón, preto da ponte de Rande, mentres o namorado presuntamente andaba nunha marea no Grande Sole:
Sentada estou na illa de San Simón
esperando, meu amigo, ai, que volvas do Gran Sol
e pola ponte de Rande van e veñen sen parar
moitos coches, meu amigo, que non veñen do Gran Sol.

Mais no texto de Reixa o amigo non andaba a pescar no mar de Irlanda, senón que, como tanta xente das rías que sofre a continua reconversión da flota, andaba ó "contrabando de tabaco e de drogas de drogar", polo que a namorada decide deixar de agardar para non se converter nunha estatua de sal.

Na literatura galega do séc. XX hai outras moitas referencias e citas textuais de versos con mar da lírica medieval. En Nao senlleira (1933) de Bouza Brey, despois da 
dedicatoria "A meu pai/ que aforcou âs musas" figuran dous versos da cantiga de Mendinho como encabezamento deste poemario fundacional do neotrobadorismo:

Cercáronme as ondas que grandes son e nen hei barqueiro nen remador.

E o mesmo no final dun poema de Contra Mar (1995) de Xesús Franco:

$$
\begin{aligned}
& \text { a galerna deixa os beixos agres } \\
& \text { e unha prez que é canto } \\
& \text { "morrerei fremosa } \\
& \text { no MAR maior" }
\end{aligned}
$$

Meendiño

Nos poemarios do Avilés de Taramancos retornado de Colombia hai referencias ó mar medieval. O poema 4 de "Nemo", de "O cántico das naves. Elexías do mar" de As torres no ar (1989) está encabezado co dístico da mariña de Johan Zorro citada:

En Lixboa sobre lo mar barcas novas mandei lavrar.

E no poema "Que rio conmove, segrel, que chúvia antiga", de Última fuxida a Harar (1992) hai referencias ó mar das mariñas de D. Dinís e Johan Zorro:

Lenes viñan as ondas e tamén na ribeira cantaban os barqueiros, os cegos trascrevian os seu desígnio (...)

El Rei manda lavrar sobre lo mar as barcas e entra a primavera nos reinos de occidente (...)

\section{Os baixos e as furnas de Pondal}

Na obra de Eduardo Pondal (Ponteceso 1835 - A Coruña 1917) conviven a gándara, a veiga e o mar. Ás veces a terra vese desde o mar, pero o normal é que se describa o mar desde a costa, o mar da batida Costa da Morte. Fóra dos mariñeiros que desde o mar ven a terra, non hai xente nas salgadas augas pondalianas. Carballo Calero (1981: 281) sintetiza nestas palabras o mar dos Queixumes dos pinos (1886): 


\begin{abstract}
Propiamente, o que se descrebe é a costa. É unha costa brava. Os fachos teñen a escura grandeza titánica de Adamastor, e amosan o calco do raio vengativo. Á hora do luceiro, que loce tímido sobre o cabo, as breves píllaras recóllense piando á negra furna, e o raposo sai da súa manida a caza de escarabellos. A fror da caramiña coroa o cabo esgrevio. Os piñeiros da beiramar son aleixoados polo vento. Tras deles escóitase o canto do mazarico. A gaivota, en bandadas, percura o reparo das illas, enchendo o vento co seu chío. O mariñeiro que entra pola Barra ou sortea os baixos de Camelle, contempra ista ribeira penascosa. Longas e vougas praias; e os esteiros onde os ríos de puras augas achan doce morrer. Fora dos mareantes que ven a terra dende o mar, non hai figuras humás nistas mariñas. Tan só o esquivo cazador a quen é anunciada a primavera pola fror da caramiña.
\end{abstract}

No poema 4 de Queixumes dos pinos o bardo bergantiñán manifesta o desexo de ser libre como as "aves aquelas/ do pico tamaño" que se van refuxiar nas illas Sisargas. Tal como indica Manuel Ferreiro (Pondal 1995: 199), o bardo bergantiñán, sen dúbida, debe referirse ós mazaricos, aves acuáticas de longo peteiro obxecto de amplo tratamento na obra pondaliana. Nos versos finais deste poema hai, entre outro léxico do mar, termos populares como baixos e furnas e cultos como sirtes:

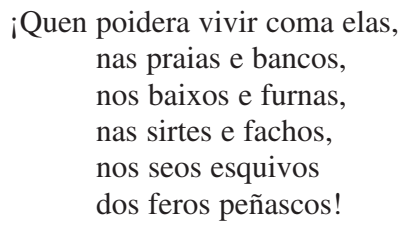

O curto poema 9 ten como tema os baixos de Camelle, que o pescador desde lonxe, debruzado na proa do barco, "está vendo branquear". No poema 85 é o bardo, que soña á beira do facho, quen "os baixos contempra/ que rompendo están”. Baixo é un termo moi popular nas falas mariñeiras para se referir a elevacións do fondo que poden impedi-la navegación. E no caso da sempre batida Costa da Morte, cando hai mar de fondo, nos baixos rompen os tombos, como tamén van romper ás praias.

Nos versos 11-26 do poema 25 "Dous rapaces, non sei onde", Pondal uso o termo pescador (e no v. 71 mariñeiros) e termos mariñeiros referidos a aves acuáticas (gaivota), a barcos (lancha) e a partes e aparellos do barco, como courel, o listón de madeira do exterior da borda dos barcos de pesca que forma a parte máis alta do costado, a vela e a escota, que é o cabo con que se goberna a vela. E usa a expresión de bolina, que se di cando se velea en zig-zag para colle-lo vento, non directamente pola proa, senón de costado na amura, de xeito que o barco ofreza menor resistencia á forza do vento: 


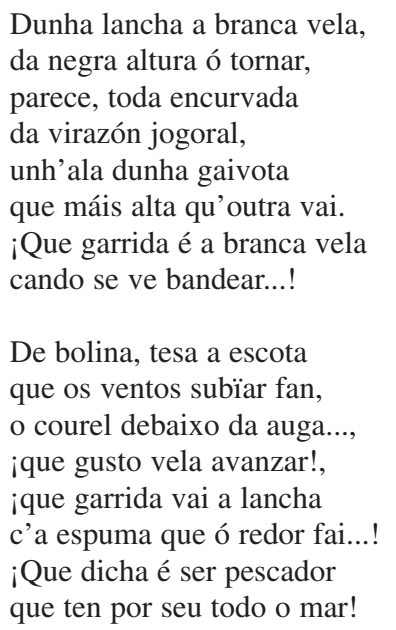

Segundo os datos da Base-ILG, Pondal introduciu no galego escrito a expresión de bolina $^{7}$ e formas como furna e courel $^{8}$. Outras veces trátase de segundas documentacións como escota e naufraxio, ou terceiras como no caso de vogar ${ }^{9}$, formas que se rexistran en versos de Queixumes.

Nos poemas manuscritos recentemente editados por Ferreiro (Pondal 2002) hai versos con ese mar e, sobre todo, con esa costa brava de que falaba Carballo Calero. Nos poemas autógrafos, no 86 "Escura está a nuite" hai gaivotas e altas furnas e a costa da areosa Arou ("costa longal", "costa pirata") onde unha "branca vela" é feita naufragar nos baixos. O poema 87 "Os baixos de Camelle" é un diálogo entre estes baixos e o Cabo Tosto, a Punta do Boi de Camariñas, con formas do mar como brétomas, baxeles, rompentes, velas, moluscos como mexillóns e percebes e o tan mariñeiro aparellar. E usa o termo areas 'praias'no poema 88 "A costa do morte".

Polo que respecta ós poemas apógrafos, a costa brava está no poema 24 "O petrelo", onde Pondal manifesta a súa admiración por este "páxaro ousado/ que na gran liber-

7 Cabanillas introduciu o verbo bolinar no soneto "A ribeira de Cambados" de No desterro (1913). Castelao empregou en 1944 a variante bolineando en Sempre en Galiza ("e se o vento se pón de proa e temos que perder moito tempo bolineando, entón cumprirá baixar a vela e botar man dos remos").

8 A forma estándar cairel ten na prosa teatral de Beiramar (1931) de Cotarelo a súa 1ª documentación.

9 A $1^{\text {a }}$ documentación de escota na Base-ILG está en Martínez González (Poemas Gallegos 1883) e naufraxio en Fernández Morales (Ensaios poéticos en dialecto berciano 1861). As primeiras documentacións de vogar están en Pintos (Contos da aldea... 1858) e Pérez Ballesteros (Versos en dialecto gallego... 1878). 
tade voando/ desprecia dos homes o pérfido trato" e que vive solitario "nos ingentes penedos marítimos/ e na punta deserta dos cabos/ saüdando as esquvas tormentas".

\section{Os salseiros e as vagas de Leiras Pulpeiro}

En varios dos Cantares gallegos o mindoniense Leiras Pulpeiro (1854-1912) presenta unha idealizada Mariña lucense, onde todo parece frescura e bondade fronte á "maldade" da Montaña:

Pra palique, as d'a Montaña;

Pra ferver logo, as valecas;

Pra frescura, as d' Mariña;

Pra querer ben, as vilegas.

$$
\text { (...) }
$$

Unha peniña do cabo

Que cobre o mar n-as marzadas,

¡Val máis que todol-os cotos,

Y-as veigas que hai n-a Montaña!

A maior idealización da Mariña verbo da Montaña faina no longo poema de 1903 "Pousadoiro", dedicado "Á Mariña”, onde, como sinalou Franco Grande (Leiras Pulpeiro 1970: 90), realizou un grande esforzo para converter unha lingua coloquial nunha lingua de cultura nos comezos do séc. XX. Na estancia $3^{\mathrm{a}}$ están a ría e a barra de Foz e as nordesías de Cantábrico:

Nin sabe o que son congostras

De trabo e lirios vistidas,

$\mathrm{Su}$ cerdeiras e loureiros

Que as gardan das nordesías;

Nin o que é, acarón dun souto,

Sentarse a mirar pra a ría,

Ou como a escuma da barra

Vai e ven, sube e rebrinca,

Mentras as mariñás soltan

Os bois e as vacas alindan

Nas pumaregas, cantando

Cantares que repinican;

Nin sabe o que é o serán doce

Dunha Mariña.

E na estancia $4^{\mathrm{a}}$ hai ondas, fúrneas e un mar que bate na $p e n a^{10}$ :

\footnotetext{
${ }^{10}$ Estas estancias están tiradas de Leiras Pulpeiro (1970: 270-272).
} 


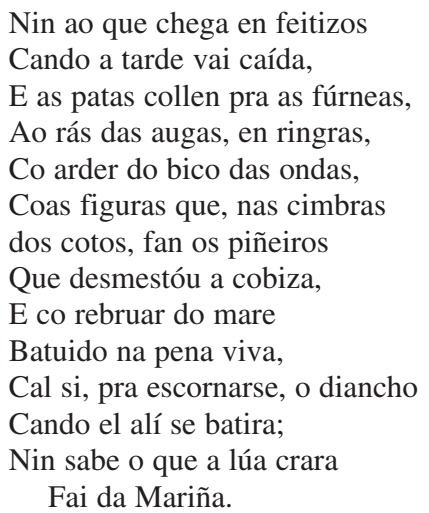

Un dos escasos poemas mariñeiros de Leiras é a composición "Engalanada, no porto", referida a unha lancha que fora a mellor e a máis feita, pero que agora podrece "arrumbada,/ No areal, ao pé das penas,/ Sin amarras e esquencida... / Hastra que unha baga veña/ E a esbandalle, e co ela arrample/ Sabe Deus pra que ribeira"). Leiras usa neste poema a forma vaga", que introduciu no galego escrito, como tamén introduciu voces tan mareiras (e tan literarias) como nordesías ${ }^{12}$, salseiros $^{13}$ e escamallo ${ }^{14}$.

\section{A marusía e os cons de Cabanillas ${ }^{15}$}

Nas primeiras obras de Cabanillas os escasos poemas de tema mariñeiro parecen cadros paisaxísticos da ría da Arousa ou ben son cantos de embarcacións da Arousa, como o poema "A trainera" de No desterro (1913), barco que en 1904 arribou desde Colindres-Cantabria a Cambados, quince anos despois de que aparecese na ría de Vigo. As veloces traiñeiras, que representaban o progreso fronte ás tra-

11 Na Base-ILG, despois de Leiras, vaga aparece en Lisardo Barreiro (Escumas e brétemas 1923), en Filgueira Valverde (O Vigairo 1927) e en Manuel Antonio (De catro en catro 1928).

12 Leiras usa nordesías en poemas de 1884 e 1903. Posteriormente rexístrase en Lamas Carvajal (Gallegada 1887), Noriega Varela (Montañesas 1910) e Manuel Antonio (Foulas 1925), na variante ultracorrecta nordecía.

13 A forma salseiros aparece nun poema de 1912. As seguintes aparicións son de Lisardo Barreiro (Escumas e brétemas 1923) e Cabanillas (No desterro 1913, Na noite estrelecida 1926).

14 A forma escamallo figura no Vocabulario gallego-castellano (1912) de Leiras. As seguintes documentacións da Base-ILG son de Manuel Antonio (Foulas 1925 e De catro en catro 1928), Cotarelo Valledor (Mourenza 1931) e Bouza-Brey (Seitura 1955).

15 Para o mar en Cabanillas véxase Fernández Rei 1999: 84-90 e 2000. 
dicionais lanchas xeiteiras, aparellábanse coa traíña, arte de cerco de xareta; e con elas traballábase, fundamentalmente, ó caldeo con raba ("a raba engañadora" dese poema de Cabanillas), engado feito con ovas de bacallao co que se atraía a sardiña, en lances de mañá e tarde, e en menor medida ó escuro, porque na escuridade a traiñeira non era tan efectiva.

O poema sen data "Veiramar" (Cabanillas 1959: 582-583) é unha homenaxe á señora da ría, a dorna, a embarcación emblemática do mar da Arousa (e da illa de Ons), que sufriu "firentes invernías", que non temeu arroaces nin refachos nin o "duro leste traicioneiro" e que agora, coa quilla ó aire, está a se desfacer no areeiro, mentres que nun dos madeiros apodrecidos pousa unha gaivota a xeito de ibis sagrada:

Tumbada, quilla ó aire,

desfaise no areeiro a vella dorna.

Groria e relembro dos lonxanos días

nos que se déu ó mar como unha noiva,

repulida e locente das carenas ${ }^{16}$,

a branca vela ó vento, cantareiro

ben presada de estopas,

nas atesadas cordas...!

(...)

Tumbada, quilla ó aire,

desfaise no areeiro a vella dorna...

Nunha cuaderna núa, apodrecida,

está pousada, inmobre, cavilosa

ollando a lonxanía,

como unha ibis sagra, unha gaivota.

A dorna e o duro traballo do mariñeiro vese reflectido no poema "Mariñeira", de 1921 (Cabanillas 1959: 153-154), co naufraxio dunha dorniña polbeira, un día de leste duro e de mar bravo. O mar ferve e o vento brúa, mais un refacho acabará coa pobre da dorna que entre salseiros, que ía coa "vela a catro rizos bolinando" e co patrón cos ollos chantados nos "cons ergueitos da lonxana costa":

16 A carena era un líquido clariño e algo amarelo que os mariñeiros de Cambados obtiñan ó quentar nun pote breu e xufre. Logo cun vespeiro, especie de fregona, dábaselle a carena en Cambados á dorna de escarva, pero non á dorna de tope. A dorna máis primitiva presenta un casco que se constrúe montando as táboas unha sobre outra en rebaixes que se denominan calimes (de aí que en Ribeira se chame dorna de calime o que en Cambados ou na Illa da Arousa é dorna de escarva). A dorna de tope, que é máis moderna, ten unha estructura interior semellante, pero con formas máis redondeadas ó usárense táboas máis estreitas, sen escarva, que se apoian a tope unhas coas outras (Leiro 1990: 93). 
Leste duro

Mar bravo.

Curiscadas da choiva.

A noite vai rubindo

cabaleira na sombra.

As fortes ás tendidas,

inquedadas, sin rumbo, silenzosas,

levadas pol-o vento

déixanse ir as gaivotas.

(...)

Un refacho asubiante

abate a verga e tronza o palo, as cordas

estalan, e un istante ábrese a vela

e cai o plan no mar...

Galgan as olas

ouveando roucas, como cans famentos

en asalto dos cons...

¡Probe da dorna!

No léxico mariñeiro arousán das primeiras obras Cabanillas emprega marusía, que introduciu no galego escrito, e os tan comúns salseiros de Leiras Pulpeiro, así coma o garimoso vento mareiro, título dunha das súas emblemáticas obras e que xa aparece no Coloquio de 24 gallegos rústicos (1746-47) de Sarmiento. En Cambados o mareiro é un ventiño maino e leve que vén do noroeste (da parte da Curota, no Barbanza) e que de abril a finais do verán adoita soprar desde a mediodia á tardiña baixa.

Un mar e un léxico diferente do das primeiras obras é o que se aprecia na obra $\mathrm{Na}$ noite estrelecida (1926), onde Cabanillas galeguiza o tema artúrico: a espada Escalibor procede da illa de Sálvora, Galahaz vén a Galicia, ó Cebreiro, na procura do Graal e na illa de Sálvora está sepultado o rei Artur. Nas sagas desta obra non hai barcos nin dornas, senón barcas e naves, misteriosas embarcacións que navegan por un mar raso, como a barquiña de Galahaz. As embarcacións atracan á luza$d a$, voz dos mariñeiros de Cambados (e doutras vilas arousás como O Grove ou Rianxo), que se usa para indicar unha tenue claridade que está entre a cos da noite e o amencer.

As barcas de $\mathrm{Na}$ noite estrelecida deixan ronsel no mar raso, mentres que a traiñeira ou a dorna das primeiras obras de Cabanillas deixaban estela, que é como en Cambados e noutras falas mariñeiras se di do fío de auga que queda pola popa do barco.

Na lingua das sagas artúricas non hai a forma cón, que se rexistra en No desterro (1913) e Vento mareiro (1915) e que é forma normal na Arousa para a denomina- 
ción dun penedo, tanto da ribeira como do monte. Agora Cabanillas prefire o termo "literario" penedo e, sobre todo, o portugués rochedo(s), que nalgún caso Cabanillas usa para as grandes pedras do mar, coma no caso de Sir Gawaine, que levaba "vinte anos/ sobre un rochedo da praia,/ batido pol-os salseiros". Cabanillas volverá usar rochedo en Camiños no tempo (1949) e en Samos (1958), o seu derradeiro poemario, pero poucos destes rochedos teñen relación co mar.

\section{O pailebote e o ronsel do mar de Manuel Antonio ${ }^{17}$}

O vangardista poemario De catro a catro (1928), o único libro que en vida publicou o rianxeiro Manuel Antonio (1900-1930) presentaba, en palabras do seu amigo Otero Espasandín, "un mar non visto aínda por ninguén. Un mar puro, sin ribeiras nin costas, perdido entre costelaciós” (Pena 1996 a: 173).

Este libro, de tantísima transcendencia na poesía galega de todo o séc. XX, comeza con estes versos (Manuel Antonio 1992: 105):

Encheremol-as velas

c'a luz náufraga da madrugada

Pendurando en dous puntos cardinaes

a randeeira esguía

d'o pailebote branco

C'as suas mans loiras

Acenan mil adeuses as estrelas

Inventaremos frustradas descobertas

a barlovento d'os horizontes

pra acelerar os abolidos corazóns

d'os nosos veleiros defraudados

Ese mar raro e fantasmagórico, cunha paisaxe mariña nunca vista e sen sentimentalismos, tamén aparece en Foulas e noutros moitos poemas do mesmo autor. É a navegación a ningures nun pailebote ó pairo (a "viaxe oximórica" de Elvira Souto) ou a navegación cara a Ítaca-Rianxo (a "odisea lírica” de Carballo Calero). Pesie tanto mar explícito e implícito, poida que o provocador e rupturista Manuel Antonio non sexa un poeta do mar e que teñamos que considerar, con Axeitos, que o mar -esa "illa d'auga rodeada de ceo por todas partes"- non era senón o medio co que el manifestaba as arelas de liberdade (Fernández Rei 1999: 93).

Os diferentes estudiosos do poemario De catro a catro parecen coincidir, como sinala Vilavedra (2000: 131), "en que a vontade do autor era unha reflexión exis-

\footnotetext{
${ }^{17}$ Sobre o mar e a lingua mariñeira de Manuel Antonio véxase Fernández Rei 1999: 90-98.
} 
tencial e o poema clave para entender a soidade ontolóxica é 'Sós"', que reproduzo na súa totalidade (Manuel Antonio 1992: 112-113):

Fomos ficando sós

o Mar o barco e mais nós

Roubaron-nos o Sol

O paquebote esmaltado

que cosía con liñas de fume

áxiles cadros sin marco

Roubaron-nos o vento

Aquel veleiro que se evadeu

pol-a corda floxa d'o horizonte

Este oucéano desatracou d'as costas

e os ventos d'a Roseta

ourentaron-se ao esquenzo

As nosas soedades

veñen de tan lonxe

como as horas d'o reloxe

Pero tamén sabemos a maniobra

d'os navíos que fondean

a sotavento d'unha singladura

N-o cuadrante estantío d'as estrelas

ficou parada esta hora:

$\mathrm{O}$ cadavre d'o Mar

fixo d'o barco un cadaleito

Fume de pipa Saudade

Noite Silenzo Frío

E ficamos nós sós

sin o Mar e sin o barco

nós.

Poida que este poema, efectivamente, sexa unha manifestación do soidade ontolóxica do home; pero, á parte disto, nese sós e nós do final dos versos 1 e 2 e, sobre todo, no nós sós do antepenúltimo verso tamén pode verse unha clara referencia ó Sinn Féin, voces gaélicas que significan nós sós, movemento nacionalista e republicano irlandés de comezos do séc. XX e co que debeu simpatizar Manuel Antonio, poeta anarco-nacionalista, como sen dúbida ningunha simpatizou Castelao ${ }^{18}$.

${ }^{18}$ O triunfo total que obtivo o partido Sinn Féin "Nós Sós" nas eleccións de 1918 seguramente explica que Castelao titulase Nós un álbum de deseños exposto en 1918, o mesmo ano en apareceron no xornal coruñés El Noroeste unhas páxinas galegas co título Nós, coa cabeceira debuxada por Castelao. E en 1920 saíu en Ourense a revista Nós, da que Castelao era director artístico. 
Na navegación por ese mar "sin ribeiras nin costas", en veleiro e en pailebote, Manuel Antonio usa léxico común no galego mariñeiro (driza, escota, penol, cazar), termos da xente mariñeira de Rianxo (melfa, rafega, mareta, ronsel, leme, peirán mallante) e léxico tomado do portugués (mastro, cais). Por outra parte, é o primeiro en usar no galego escrito moitos termos técnicos ou científicos relacionados coa navegación do barco (morse en Catro, rosa dos ventos, roteiro, meridián, desacompasar) e outras diversas formas mariñeiras, como o galicismo rol, o lusismo cais e as tan mariñeiras barlovento e sotavento (Fernández Rei 2001: 247 248).

\section{A nao e o cachemare de Bouza-Brey}

O neotrobadorismo, movemento poético que buscaba unha renovación da tradición poética medieval, ten en Nao senlleira (1933) de Fermín Bouza-Brey (Ponteareas 1901- Santiago de Compostela 1973) un dos referentes principais. Moitos dos poemas do libro xa se publicaran entre 1925 e 1932.

Como xa sinalei máis arriba, Nao senlleira ten como mascarón de proa dous versos de Mendinho relativos ó mar e á soidade, temas recorrentes na obra de Bouza. A paisaxe mariña do libro é "unha transposición da paisaxe da alma, da comunidade do individuo co contorno que se integra plenamente na natureza", e nesta obra a nao é o símbolo axial, tal como sinalou Ramiro Fonte (Vilavedra 2000: 325-326).

Nos primeiros versos do poema "Trova infinita" (1926) hai moi diverso léxico mariño, case todo el culto: treu, navega, porto, arribar, bujola 'brúxula', áncora, mariñar, mariñeiro, nao, abisal e serea (Bouza Brey-Trillo 1980: 26):

Con treu de espranzas navega

-ai Deus!- o meu corazón,

soñando portos iñotos

onde ninguén arribóu.

Nin estrelas nin bujolas

nin áncoras no seu prol;

mariñan os mariñeiros

do pensamento e o trebón

guinda ca nao senlleira

nas abisales paixóns,

Ai Deus!

Salvade, louras sereas, ao meu corazón! 
Todas estas formas xa tiñan tradición literaria, agás treu 'velamio' ${ }^{19}$. O verbo mariñar, que introducira García Ferreiro, aparece no poema "En corso" de Curros ${ }^{20}$.

No poema de 1927 "Tríadas no mar e na noite" (Bouza Brey-Trillo 1980: 28-29), a embarcación desígnase cos termos cultos navío e nao e cos populares gamela e chalana. Neste texto a "nao" ten mastro e treu e Bouza non usa o popular baixo(s) de Pondal, senón baijío ("corazón-baixío") usado por Cabanillas ("baixíos costeiros") na Noite estrelecida (1926):

Meu navío leva ao vento

no mastro eterno da noite

o treu do meu pensamento.

Leda vai a nao

na proa unha frol:

a rosa albariña

do meu corazón.

Amiguiña, crara estrela,

dame a aguillada de un bico

para apurrar a gamela.

Leda vai a nao, et sic.

Por navegar ao desvío

varei a miña chalana

no teu corazón-baijío.

Leda vai nao, et sic.

(...)

Na primeira estrofa do poema de 1931 "No anal de Manoel Antonio" (Bouza BreyTrillo 1980: 46), áchase léxico mariño culto de textos do poeta de Rianxo (mastro, nao, singladuras). Na segunda estrofa o léxico é popular da Arousa (boureles, rapeta e "ramallada de loureiro" do bourel, pesca); e na terceira estrofa hai referencias á obra e á profesión de Manuel Antonio, á vez que introduce no galego escrito o termo culto bitácora. Remata ese poema-aniversario co avante tan popular nas falas mariñeiras:

19 Pondal utiliza treos nun verso de Os Eoas ("E treos e bonetas peregrinas"), segundo información de Manuel Ferreiro, que ten preparada a edición desta obra a partir do texto de Pondal que achou na RAG.

${ }^{20}$ As primeiras documentacións son de García Ferreiro (Volvoretas 1887), Curros Enríquez no poema "En corso" de 1898 ("Mariñeiros da Marola/ de illas Cíes e do Orzán/ (...)/ aprestáivos, mariñeiros,/ pola patria a mariñar"), Xan de Masma (;A besta! 1899) e neste poema de Bouza. 
Poeta, no teu posto, decote vigiante, de catro a catro, a eterna bitácora ja diante, eres piloto "en seco", no mar e na outra vida:

¡Aaa... vante!

No poema "Parranda mariñeira" (1932), dedicado a R. Carballo Calero, a "nao" é un cachemare (9 rexistros), o quechemarín e queichemarín dos documentos de Taboada Roca nas notas históricas de Terra de Melide (1933), e que constitúen as primeiras (e escasas) documentacións no galego escrito. Tamén usa neste texto masteleiro, que introducira na poesía Amado Carballo, en Proel (1927). E no poema "Regueifa" (1932), a " flor das naos" é a balandra (dos 'Ultreya'), termo que constitúe a primeira documentación no galego escrito.

Hai outro léxico mariño do poemario que merecería comentarse, como cons ("Agárdanos na ribeira/ sob o descordo do mar/ no seo dos cons o leito das herbiñas de namorar...”) das "Leilías ao teu ouvido" (1933), os populares cons da Arousa onde se criou Bouza, e o "literario" penedos de beiramar onde se escachan "as sete naos pulidas", da "Trova das sete naos" (1929), onde tamén aparece o treu.

En Seitura (1955) hai léxico do mar por todo o poemario, especialmente na composición “O pescador de baleas grandes” (Bouza Brey-Trillo 1980: 68-69), con termos populares (balêa, arpão, raba, amarrara ou salseiros), algún termo culto como marear ("Cando mareasse de cara a Islândia") e unha voz como cabadelo 21. No breve poema "Tópico no porto" (Bouza Brey-Trillo 1980: 81) emprega as voces populares amura, rapaz de a bordo, devala ("O mar devala, devala), praia, marinheiro, remador e falua.

\section{A carriola e a dorna de Cunqueiro}

Seguindo o ronsel de De catro a catro Álvaro Cunqueiro (Mondoñedo 1911- Vigo 1981) publicou en 1932 un breve poemario Mar ao norde, pero pouco ten en común co mar de Manuel Antonio. Para Carballo Calero (1981: 751) o mar de Cunqueiro "é máis ben 'cubista' que "creacionista" e máis que "crear un mundo, esquematiza o existente. Todo son descripcións metafóricas, sintéticas, ás veces ambiguas".

21 En Santamarina (2001) só se rexistra no diccionario de Carré, que define cavadelo como "lugar arenoso en las rías, que, al quedar en seco, durante la bajamar, se cava para coger almejas y otros moluscos". No terreo gañado ó mar no porto de Vilagarcía hai unha Rampa de Cabadelo, e probablemente Bouza coñeceu na súa infancia nesa vila un cavadelo como o define Carré. Na Base-ILG hai outra documentación de cavadelo en Anos de viaxe (1987) de Rodríguez Baixeras. 
O léxico mariño deste poemario está xa nos títulos das tres primeiras partes do libro: "Porto", "Mar outa" e "Illa" (a cuarta é "Terra adentro"). Nos poemas o léxico do mar está constituído por formas literarias (ronsel, pleamar) e populares de moito uso literario (illa, praia, gueivotas, navegante, navegacións, lancha, mar, mareas e vento). Usa a forma algas á vez que introduce no galego escrito carriola ${ }^{22}$ ("carriola de pedra dura") no poema 5 de "Illa". Trátase dun tipo de alga, que despois de Cunqueiro vai rexistrarse en Cómaros verdes (1947) e noutros poemarios de Iglesia Alvariño.

O poemario Cantiga nova que se chama riveira (1933) é o libro "máis vizoso, máis lizgairo, máis lanzal de Cunqueiro", o que fixo que se incluíse a este escritor no neotrovadorismo (Carballo Calero 1981: 752). A este poemario pertence esta fermosa cantiga, a 21 da ed. ampl. de $1957^{23}$, que é a única do libro con referencias xeográficas:

Si miña señor á i-alba da Arousa beilar poñereille, belida, un ventiño no mar.

$$
\begin{aligned}
& \text { A dorna vai e ven } \\
& \text { que meu amor ten! }
\end{aligned}
$$

Poñereille unha frauta e máis un reiseñor e unha longa soedade coma a da mar maior

A dorna vai e ven

que meu amor ten!

Na illa de Cortegada poñereille un galán por pastor das mareas co seu remo na man.

A dorna vai e ven

que meu amor ten!

Poñereille unha gaita no bico da ría e unha avelaneira no medio do día.

A dorna vai e ven

que meu amor ten!

${ }^{22}$ É a Chorda filum, que no galego mariñeiro ten como denominación xeral correa e como denominacións locais, entre outras, carriol en Bueu, carriola en Cesantes e Mogor, correola en Malpica e Camariñas, correolo en Cangas, corriola en Cesantes, Miño e Ares e curriola en Caión e Mera (Ríos Panisse 1983: 53-55). A forma correola rexístrase na glosa da copla 30 do Coloquio de 24 gallegos rústicos (1746-47), de Sarmiento (1970: 338): "Correola, diminutivo de correa, y todo del latín corrigia es una especie de espadañitas que el mar arroja y que representan unas correas regulares de una vara de largo. Y a ese género de correas, cuando son más anchas al doble de la correola llaman seba, ceba, $x e b a$, y en el Ferrol oí llamar xebra; pronunciando la X en xebra y xeba como los gallegos la pronuncian: sibilándola como su CH los franceses". Na Base-ILG as diversas documentacións de correola refírense a unha pranta ("Teño unha herba na horta que lle chaman correola"), agás en Patria do mar (1989) de Darío Xohán Cabana ("o plancto, as correolas e as sardiñas").

23 A ed. de 1933 publicada en Ronsel, contiña 19 cantigas. Na ed. ampliada de 1957, en Monterrey, engadiuse a 20, que non se publicara antes, e cinco novas cantigas, numeradas de 21 ("Si miña señor á ialba da Arousa beilar") a 25 ("Por oír a unha rula decir de amor"). A cantiga que reproduzo está tirada de Cunqueiro (1991: 65). 
A paisaxe mariña da Arousa, a ría e a illa de Cortegada, no fondo da ría, fronte a Carril e veciña das illas Malveira, máis ben illeus. Supoño que Cunqueiro sería sabedor da homenaxe popular que en 1936 quería "consagrar a illa de Malveira á memoria do noso gran poeta do mar", a Manuel Antonio, tal como manifestaba en A Nosa Terra o galeguista Xan do Río (Capelán 1996: 39).

Léxico común desta cantiga son ventiño, mar (e o mar maior de reminiscencias da lírica medieval), mareas, remo e dorna, a embarcación emblemática do mar e das ribeiras dos dous costados da Arousa, o do costado de leste onde está a illa de Cortegada e o costado de noroeste onde está Aguiño e Carreira, de onde viñan as dornas carreiranas. A popular dorna tiña unha gran tradición no galego literario, con primeira documentación en Galicia. Revista universal de este reino (1861).

Polo que repecta ó léxico mariño hai vento mareiro na cantiga 2 ("Colgaban vento mareiro/ na i-auga de terra firme") e outros ventos, como o tolo da cantiga 3 ("romería de vidrados,/ cu-có para vento tolo"), e o vento perdido e irado da cantiga 23, aínda que estas non son cantigas de mar. Outros termos son formas comúns e literarias, como alga, escuma, onda, sal, sirea, riveira, nao, mariñeiro e navegada.

Na sección de "Cantigas" que fechan o poemario Dona do corpo delgado (1950) Cunqueiro continúa o achegamento á lírica medieval galego-portuguesa, á vez que fai libres adaptacións do "rondeau" francés (Vilavedra 1995: 158). Hai diverso léxico do mar ó longo do libro, pero especialmente na II das "Cantigas do amor cortés" (Cunqueiro 1991: 124), unha fermosa mariña, onde a "nao" primeiro é o quechemarín, e logo o navio; e nesa mariña, con reminiscencias do mar de Martín Códax ("ondas amigas do mar levado"), zoa o vento norés e é interpelada unha sirea:

Quechemarín da verde bandeira, o mariñeiro ú é?

Ondas amigas do mar levado, o mariñeiro ú é?

Norés que tés a aza lixeira, o mariñeiro ú é?

Ti sirea que cantas soñado, o mariñeiro ú é?

Limós no áer navíos no mar, prendas de amante pra quén serán?

Ai!, xa sinto os remos madre no mar, meu amigo novo non tornará! 
No resto do poemario o léxico do mar practicamente se reduce a formas como marea, o/a mar, vela, veleiro, nao, naves, illas, gueivotas, peixes ("peixes prateados") e algas.

\section{Os tombos e coídos de Zapata García}

A Costa da Morte e Laxe están presentes en moitos versos de A roseira da soidade. Poesías galegas (La Coruña, Roel, 1957) de Antón Zapata García (Laxe 1886Buenos Aires1953). Este poeta é unha figura, en xeral, descoñecida na cultura galega. Estivo emigrado en Buenos Aires a comezos do séc. XX, onde foi directivo da arredista Sociedade Nacionalista "Pondal".

Otero Pedrayo no prólogo dese poemario póstumo sinalaba que a existencia dun "pneuma argonáutico sinon precisamente ulisaico nalgúns poemas mariñáns de Zapata e seus apaixoados periplos da costa bergantiñán pois sempre as vellas e labouradas testas dos promontoiros axexan e vixían como rexas esculturas da idea fonda, lonxáa e consoadora das 'Matres' galegas".

Para Carballo Calero (1981: 607), o galego vivo do poeta de Laxe "é ricaz, especialmente en termos náuticos, e se a el se houbera atido, houbera logrado unha linguaxe propria, precisa i enxebre", pois cando Zapata escribe versos de tema mariñeiro "logra os seus mellores momentos".

Na paisaxe mariña de Zapata están as laxenses Pedras de Besugueira ("lambidas pol-as olas e os algazos/ que as fortes maresías, do coído/ trouxeron ao relanzo"), os baixos do Roncudo de Corme, os cabos da costa da Morte cos seus faros ("Diante das crucelladas dos baixíos/ fronte aos cabos que afían seus penedos/ Touriñáns e Fisterras,/ Ortegales, Viláns e Currubedos-”) e a vila de Laxe, que se espella "n-as ondas tranquías, coor turquesa/ pieitando os seus cabelos de ourífica finura", con praias que en verán son leitos de puntillas onde sestean "as peixadoras quillas/ sin relembrar nortadas, trebóns e furacáns” (Fernández Rei 2001: 238).

En A roseira da soidade hai léxico referido a ventos (nordés, nordesía, nortada, noroés, refachos) e a mareas (maresía, socheos), e para a xente do mar rexístrase peixeiros, peixadores e pescos, xunto co verbo peixar. E o movemento do vento provoca ondas, vagas e vagallóns, mais tamén os fisterráns tombos ("tombos galgantes e ruxintes, con louco revoar"), as grandes vagas que se producen cando hai mar picado e que rompen nos baixos ou nas praias e que usaran os muxiáns Victoriano Abente e Gonzalo López Abente ${ }^{24}$. Zapata fala de furnas (e furnals),

\footnotetext{
24 Antes de que Victoriano Abente usase tombo en 1881 ("tombos de mar fervendo"), X. M. Pintos introducira a variante tumbos en 1853 ("os tumbos [da Lanzada] que escumaban a cachóns").
} 
rochedos e coídos, pequenas enseadas con pedras traídas polo mar, tan frecuentes na batida Costa da Morte.

Algúns dos poemas de Zapata recompilados en A roseira da soidade editáranse 30 anos antes, como "Chuco da dorna. Mariñeiro galego" (en Céltiga, 25-7-27) ou "Alando a traíña" (A Nosa Terra, 1-12-27), onde canta a escrava vida da pesca de baixura, usando termos comúns (halar, panos, paneta, traiña, salmuira...) e algunha expresión tan común cal "peixe como area":

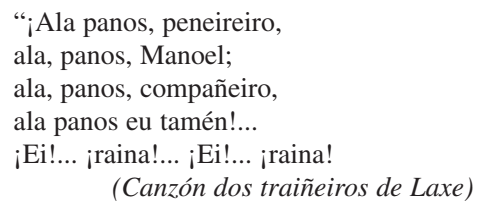

O rosáreo de corchos e aparello os barudos peixeiros vân alando, e das gorxas sonouras sái o vello cantar que fái mil anos vên cantando:

Ala panos, peneireiro, ala panos na paneta; ¡ala panos, compañeiro, que hoxe hay peixe como area!

E, ao rolán do estribelo

Os seus corpos balanzan:

-¡Ei!... ¡raina!... ¡Ei!... ¡raina!

Mentras alan, descalzos, a traíña, e, â salmuira mestúranse os suores, revoa, câl revoa unha anduriña, a trïada que conta as súas dôres:

-Sempre, ¡sempre!, traballando, dende a mañán hastra â nuite... ¡e sempre probes ficamos!...

\section{A augama e as xerfas de Cuña Novás}

No longo poema "Trebón perpetuo" (1951) de Manuel Cuña Novás (Pontevedra 1926-1992) figura un mar desacougante, con gueivotas "cal sotiles agoiros/ diante das furnas mouras", con augamas 'medusas' (as rianxeiras melfas de Manuel 
Antonio) que "aboian nas tebras estantías", con vixiantes ollos "do mariñeiro erguido no cimacio da anguria", con mulleres anguriadas que desde terra esculcan o barco enfrontado ó trebón:

Póla anguria das mulleres que esculcan desde as cons o erguido mastro senlleiro, o velamio firme ao trebón perpetuo do destiño e que atopan na praia o remo soio ou a faciana descoñecida moito tempo ousesa do que ninguén contou o istrano acontecer.

Na xerfa do mar frúe o sangue cristaíño como un ronsel á popa de morte afirmativa. (...)

A forma aguamá foi introducida no galego escrito por Fuco G. Gómez en O idioma dos animás (1937) e ten as seguintes documentacións nos varios rexistros de augama no poemario Fabulario novo (Pontevedra, Benito Soto, 1952), onde se incluíu "Trebón perpetuo", e na augamá de Patria do mar (1989), de Darío Xohán Cabana e na augamar dos quintetos de Miro Villar de Gameleiros, mar de rostros (2002).

Cuña Novás usa neste texto léxico culto e popular empregado por Manuel Antonio: xerfas ("xerfa do mar", "xerfa das ágoas") e escuma, ronsel e foula ("foulas rodantes", "foulas núas"), navío e naufraxio, rafegas (de vento) e desarbolado, mastro(s) e velamio, roteiro e cordaxes, remo e mariñeiros, praia e furnas. Emprega as formas búxola e mareia, que en Manuel Antonio son búxulas e mareas, e a forma cón, con xénero feminino ("sobor das cons que teñen a dór do arraigamento", "Pola anguria das mulleres que esculcan desde as cons"), ó igual que no derradeiro poema da sección "Costelación de intres" de Fabulario novo ("Que a terra é nosa e tén as cons acesas").

Nos restantes poemas deste libro o léxico do mar en parte é semellante ó de "Trebón perpetuo", con varias xerfas ("en col dun ramaxe núo que refrexou a xerfa", "caen na xerfa maína solermiños", "xerfa dos degaros", "xerfa do aer pousada"), escumas, foula (dos naufraxios, do silenzo, de terra), ronsel (de tebra anguriante), augama e mariñeiro. Entre os escasos termos que non figuran en "Trebón perpetuo" están costas, barca, barqueiro con varios rexistros, ría e falúa.

\section{Os carrumeiros e a goldría de Bernardino Graña}

O poema "Trebón perpetuo" de Cuña Novás está dedicado ós mariñeiros de Cangas, Vigo, Bueu e Baiona. E se cadra foron estes versos os que levaron a 
Bernardino Graña (Cangas do Morrazo, 1932), a compoñe-la "Oda ós mariñeiros de Cangas" e outras composicións de Profecía do mar (Vigo, Galaxia,1966) onde canta a xente do mar.

No poemario de Bernardino o mar xera vida, mentres que o home é monstro destructor, "un estranxeiro deste cosmos orixinal e total, que abala entre atracción e medo" (Vilavedra 2000: 385). Trátase da primeira obra da literatura galega onde a dura vida da xente do mar, a xeito de épica de loita co medio, se converte en protagonista de denuncia. E para isto o poeta válese, fundamentalmente, da fala mariñeira de Cangas, como na citada "Oda", da que se reproducen as primeiras estrofas:

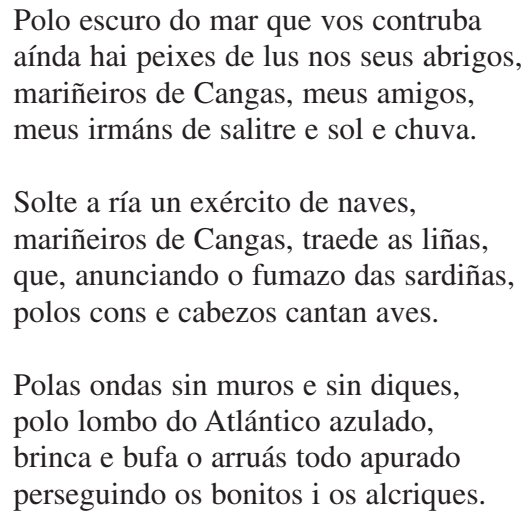

$\mathrm{Na}$ "Oda" hai termos sobre a configuración do terreo como os baixos vistos en Pondal, e sorríos, fondos mariños, xunto con termos relativos ás pedras como cabezos e cons. Estes son as pedras da ribeira e dos arrecifes, de forma máis ou menos redondeada e que se amorean sobre outras pedras, sen base firme no fondo do mar, mentres que o cabezo é unha pedra que sobresae como unha cabeza da superficie e que ten a base no fondo do mar e non sobre outra pedra como o cón (Graña 1966: 75).

Outro léxico ben mariñeiro desta "Oda" refírese ás augas. Son termos como espumallo, a escuma fresca do mar que xorde das ondas e da rompente; ardentía, a fosforescencia ou luminosidade das augas do mar ó seren removidas por "noctilucas" e que se dá nas noites sen lúa; ou fumazo (con seseo de Cangas) para o manchón que a sardiña ou outro cardume calquera produce no mar, especialmente nas noites de ardentía. No léxico da fauna e flora mariña aparecen na "Oda" formas propias do Morrazo como cercella 'estrela do mar', aguaneira 'medusa' e carrumeiro, unha alga mariña de talo longo e groso e de cor acastañada (Fernández Rei 2001: 228-229). 
Na "Carta a Tío Emilio e aos seus compañeiros, os mariñeiros de Cangas" de Non vexo Vigo nin Cangas (1975) figuran termos para accidentes xeográficos como congorsa para un lugar intrincado e laberíntico, encaixonado a xeito dun pequeno refuxio onde entra o mar e que pode ter unha praia; e termos para as augas como roncallo, onda producida polo vento que avanza rectilínea e en paralelo á costa, con crista de escuma e con moita forza, formas que usara en Profecía do mar (1966). E nesa "Carta" ó vello mariñeiro de Balea zoa o arousán vento mareiro de Cabanillas.

Na composición "Pregunto aos homes e ás mulleres do noso mar" (Graña 1995: 9293) de Non vexo Vigo nin Cangas, o autor diríxese á xente que vive do mar, á do Cantábrico e do mar Ártabro, á da Costa da Morte e das rías Baixas, á que anda ó marisco nos areeiros, cons e praias, á que pesca coa ardentía e á que traballa nos laños, voz que xa aparecía en Profecía do mar para os pozos entre pedras e argazo onde abundan familias de peixes:

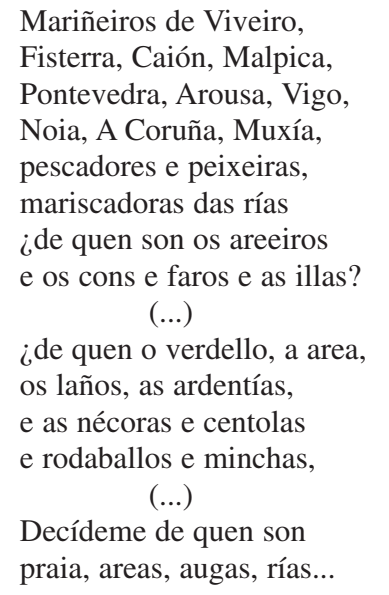

\section{As cabernas e as crebas de Méndez Ferrín}

O poema "Ós líderes mariñeiros que fuxiron na dorna e morreron no Atlántico, lonxe do terror" (1967), recompilado na sección de "Elexías nacionais" da Antoloxía poética (1972) asinada co heterónimo Heriberto Bens e logo editado en Poesía enteira de Heriberto Bens (Vigo, Xerais, 1980), ten nos versos das partes I e II léxico mariñeiro con moita tradición literaria (area, foz, vagas, salitre, gamela) e moi diversos rexistros de mar ("O asesino non coñece o mar. / O mar é voso. / E voso enteiro, todo, sin lindeiros"). Outras veces son nomes de peixes tan diversos como escalos, sardiña, morea, faneca e faneca francesa. 
Nos primeiros versos da parte III do poema hai léxico da dorna, como arca e couso, que Ferrín introduce no galego literario ${ }^{25}$ :

E a dorna desperezou os longos remos.

Os longos remos sobre as remadoiras do medo.

O medo, coma un estrobo, enguedellouse na caberna.

Na caberna de arca,

na caberna de couso.

Dende a roda de proa ás rabeiras de popa.

O bateren as pás sobre as vagadas avesedas,

a dorna era un grande arau ferido, unha

gaivota agoníada, ave crebada.

A arca (banda de estribor), o couso (banda de babor), a caberna de arca, a caberna de couso, as remadoiras dos remos, a roda de proa (peza vertical grosa e curva que forma a proa do barco, unida á quilla e de onde arrincan os costados das amuras) e outro léxico desta elexía nacional aparecera na obra de Ricardo Mora Hombres y dornas (1965), tal como se nomeaban nos anos 60 no concello de Ribeira.

Na parte IV do poema hai léxico mariñeiro con tradición literaria, unhas veces son termos de introducción recente como o carrumeiro (tipo de alga) ou a goldría (remuiño da auga nas pedras que arrastra escuma e substancias como algas e area, ou ben unha resaca forte) da Profecía do mar (1966) de Bernardino Graña. Outras voces tiñan tradición, como o verdello de Sarmiento ou o argazo de Manuel Antonio e de Zapata.

Na serie de poemas "Quai des Brumes" de Estirpe (Vigo, Xerais, 1994), Ferrín mestura a intrahistoria con libros de aventura da mocidade, co que crea unha xeografía fantástica con personaxes literarios e reais, navíos históricos e naufraxios famosos, que na clausura se presenta como relato ficticio das tabernas mariñeiras da ría de Vigo (Vilavedra 2000: 190). Por eses poemas andan o pirata Benito Soto e o seu barco "La Burla Negra", o pailebote "Constantino Candeira" de Manuel Antonio e os queches $^{26}$ de Noia, Ulysses Fingal e os mariñeiros de Malpica que

\footnotetext{
25 A arca e o couso rexístranse en obras de Ferrín de 1976, no poemario Con pólvora e magnolias e na novela Antón e os iñocentes, e logo na prosa de Arnoia, Arnoia (1985) e Bretaña, Esmeraldina (1987). No galego non literario hai varios rexistros de couse (e a variante couso) e de arca en Mörling (1989) e na lingua literaria rexístrase arca e couso en Bernardino Graña (Fins do mundo 1974) e en Martínez Oca (Náufragos en terra 1995), arca en Alfredo Conde (Xa vai o griffón no vento 1984) e en Darío Xohán Cabana (Patria do mar 1989).

${ }^{26} \mathrm{Na}$ Base-ILG a $1^{\text {a }}$ documentación de queche está en Pé das Burgas (1896) de Álvarez Novoa ("de chalanas, de galeós, de queches e algunha xeitosa goleta”). A seguinte está en Estirpe de Ferrín, á parte do quechemarín de Cunqueiro e o cachemare de Bouza-Brey.
} 
andaban ás crebas -restos que o mar devolve á terra, especialmente restos de madeira- e que fixeron ceifa nos dentes de ouro dos afogados, e andan o piloto, o gavieiro e o rapaz de Manuel Antonio.

No penúltimo poema desa serie, "Coma un arau corre a tormenta", en que Ferrín trata a internacionalización da flota dos caladoiros do Grande Sole (Fernández Naval 1999: 42), aparecen formas populares como arau (ave mariña), racú (embarcación) e folio (matrícula dun barco), que introducira Dieste en Dos arquivos do trasno (1962):

Coma un arau corre a tormenta

o racú fantasma, finalmente acóllese

á Buraca do Inferno.

"Eu mirinno en Ons o día de Venres Santo, inda se lía na ponte: "Norita".

"E o folio?"

"O folio éralle de Brest, Don José María".

O derradeiro poema da serie "Quai des Brumes" é, en certo modo, unha homenaxe ós dous grandes "poetas do mar" do séc. XX, Manuel Antonio e Bernardino:

Daquela foi cando o patrón da lancha xeiteira ordenoulle aos homes ciar todo de couso, pero isto é unha estoria de arroaces insomnes que inda non foi contada nas tabernas de Cangas.

Entrementres

tatexan as paipas co ademán políglota das bandeiras

\section{Os mastros do navío Lorref de Xohana Torres}

"Estacións ao mar" é o cuarto libro do poemario Estacións ao mar (Vigo, Galaxia, 1980) de Xohana Torres (1931), natural de Santiago pero ligada a Ferrol na infancia e parte da mocidade. O mar é o principal protagonista dese libro de madurez, un mar a que estivo unida desde moi nova por ser filla e muller de mariño e ter feito moitas viaxes por diversos mares e océanos, vivencia viaxeira aludida nestes versos:

¡Estación de ir e vir coma na ponla os páxaros!

Recorrín tantas rías

os raros viaxeiros, os grandes trasatlánticos. 
Vilavedra (2000: 187) considera que este libro representa a presencia do mar na vida da autora, a esperanza da liberdade e a infancia e a mocidade en Lorref (anagrama de Ferrol), navío onde se atesoura a imperiosa necesidade de navegar:

Ouh, Lorref, corazón de navío, dique grande de todos.

Ninguén retorna do gran reino do mar, mais dudo que en tí non flote aínda como unha rosa a vagabunda vocación do home.

A noite do mar denota soidade e convicción da morte:

Lenta, guardiana noite e tan segreda cando estabelece o outono as doces horas.

Luces quetas dos mastros que non chegan a nós, que se retiran.

Densa, solene noite:

Un mar escuro, un súbito paxaro, que se anuncia entre $\mathrm{o}$ aleiro e as parras.

(...)

Orela aínda, volveremos a tí, noite, en silencio.

En palabras de Vilavedra (2000: 187), a navegación, os afogados e a morte "vistas deste este barco de terra que fai esquecer a ribeira (Lorref) lembran o entramado simbólico-existencial de Manuel Antonio en De catro a catro".

No poeta de Rianxo hai termos cultos e literarios, mais tamén vocabulario mariñeiro propio da Arousa ou de Rianxo, como antes indiquei, mentres que o vocabulario mareiro de "Estacións ao mar" é común, popular ou culto, pero sen dialectalismos. Xohana Torres usa termos literarios como mastros, nau, orela e ronsel, formas como roca (e non o cón das Rías Baixas nin os literarios rochedo e rocha) e voces comúns como area, o omnipresente mar, mariñeiro, naufraxio, praia, peixe, redes ou vento.

Común é o léxico relativo a tipos de barcos (trasatlánticos, remolcadores, navíos, vapores, lancha e as literarias barca e dorna), a accións coas embarcacións (transbordar, varar), ós lugares de atraque (porto, dique, beiramar), á navegación (vela, vento, ruta e non a literaria derrota) e ás augas do mar (ondas, espuma, corrente, correntada, devalo aplicado á noite). E o mesmo ocorre coa escasa flora e fauna 
marítimas do libro (algas, algazos e gueivotas). A a excepción deste léxico común serían as xebras, un tipo de alga, do primeiro poema do libro: "aquel cheiro de xebras e de algazos/ do mar que tanto amei” (Fernández Rei 2001: 250-251).

No léxico das outras partes de Estacións ao mar os termos son mar e marea, ondas e espuma, ínsua(s) e illa, ría e praia, vento e nordés, barca e nao (e a popular lancha), ronsel e mastro, océano e naufraxio, caracola e agallas (gal. galadas ou guerlas).

\section{O remo e o adival en Avilés de Taramancos ${ }^{27}$}

A paisaxe labrega e mariñeira da infancia vivida na aldea de Taramancos-Noia explican que a terra e o mar estean en maior ou menor medida presentes en toda a obra de Avilés, xa desde o seu primeiro poemario As moradías do vento (1955).

En Cantos caucanos (Santiago de Compostela, Sotelo Blanco, 1985), nos poemas da primeira sección, co mesmo título có poemario, hai diverso léxico relacionado co mar; pero realmente a temática mariña está nos sete poemas da sección titulada "Crónicas", xa desde o epígrafe onde o autor trata o mito de Ulises representado na figura homérica de Nausikaa, filla do rei dos feacios, xunto co refrán da cantiga "Mia irmana fremosa, treides comigo" de Martín Códax:

Soñar, soñei a Illa: que ela non existía; e soñei na xunqueira a voz de Nausikaa. O corazón agora, náufrago do regreso, Ten soidades do mar...

... E miraremos as ondas.

O poema I da "Crónica de Bernaldo Fros" (Avilés 1985: 49-50) comeza cun verso dunha cantiga de amigo do trobador portugués Gonçal'Eanes do Vinhal (“Quand'eu soby nas torres sobre lo mar"), mais realmente a relación intertextual do poema ten que ver coa "Balada del puerto de Os", de Urbano Lugrís, viaxe de "alucinación e pesadelo, pois o de Os non é senón o porto dunha cidade morta" (Capelán 2002: 24):

Deixaramos o porto de Os

o país etéreo onde Ulises Fingal tecera un soño

de fragatas errantes, de afogados

nídios no seu clamor como coitelos

relocindo na noite.

Deixaramos o porto de Os. A alta proa

collía rumbo ás illas.

27 Voume referir unicamente ó mar da poesía do seu retorno a Galicia. Para o mar na prosa e en toda a poesía de Avilés véxase Fernández Rei (2003b). 
A composición "A crónica ferida -elexía menor-", derradeira composición dos Cantos caucanos, para Capelán (2002: 26) é un dos textos máis logrados do volume e, se cadra, de toda a obra de Avilés. Ese poema condensa en certo modo "a poética implícita da composición da primeira parte do poemario, ao tempo que anuncia desde o punto de vista formal os versículos de grande alento de As torres no ar".

En "A crónica ferida" hai moi diverso léxico mariñeiro, como fanal, arboradura, beiramar, ancorar e porto.

Os poemas de "O cántico das naves. Elexías do mar", sección segunda de As torres no ar (Santiago de Compostela, Sotelo Blanco,1989) teñen todos un mar explícito, con navíos e mariñeiros, con personaxes literarios do mar (o Ulises de Homero e o capitán Nemo de Jules Verne) e con espacios significativos relacionados coas descubertas e coas lendas do mar, como Moçambique, Timor-Leste, Calicut, Goa e outros (Arxóns Álvarez /Castro Rodríguez 2003: 98).

A subsección "A nave do tempo", con tres poemas non numerados, constitúe un canto ó mar da infancia do poeta. No texto 1 están presentes "as vellas naus" que o tempo levou, os "antigos velames" que na maré "orzan/ as quillas" e a driza que canta "nos mastros do amor". O texto 3 é outro canto á navegación e ás velas, o foque e a (vela) escandalosa ("O velame, do foque á escandalosa, tenso no ar/e a proa a peitear as ondas"). E o texto 2 é un canto ós calafates constructores e arranxadores de barcos, onde aparece a forma galipote da Costa da Morte (e da Mariña de Lugo e zonas próximas), de escaso uso no galego escrito, e non o chapapote $^{28}$ de Noia (e doutros portos da ría), hoxe popularizada pola marea negra do Prestige:

Na outra banda do mar construen o navio:

o martelar dos calafates resoa na mañá, e non saben que están a construír a torre de cristal da miña infáncia.

Non saben que cada peza, cada caderna maxistral é unha peza do meu ser. Non saben que no interior da quilla está a médula mesma da miña espiña dorsal; que no galipote a quencer está o perfume máxico da vida.

Que cando no remate ergan a vela, e a enxárcia tremole vagarosamente no ar será o meu corazón quen sinta o vento, será o meu corazón.

28 Chapapote, que está moi documentado, foi introducido por Pérez Placer (Contos da veira do lar 1901), mentres que galipote ten as primeiras documentacións en Leiras (galipota no Vocabulario gallego-castellano 1912) e en Zapata García (A roseira da soidade 1953). 
A subsección "Nemo" fórmana seis poemas numerados, con moi diversos elementos épicos rigorosamente estudiados por Capelán (2003: 27-29). No poema 1 o poeta diríxese ó capitán Nemo, o personaxe da novela Vingt Mille Lieues sous les mers de Jules Verne, porque quere entrar no Nautilus e "ver no fondo do mar antigas naves,/ antigas rotas, herois, mariñeiros/ dos tempos idos" e quere recuperar "as goletas da infáncia a toda vela", as que Avilés vía de neno na ría de Noia.

No final do poema 5 aparece o mar ("cabrestante") e a terra ("fouce", "bigórnia"), a Galicia do remo e a do adival, como en moitos outros versos:

Noso é o remo e o adival. Herdamos esa triste atadura, e o noso amor ao mar foi-se esvaindo nos trigos da na miséria.

meseta

Nosa non foi a espada: Noso foi o tear, a obra negra, ir semeando os campos asolados tras os carros da

(Mentras nos abateron as murallas da pátria). guerra.

A subsección "A espada florescida" féchase co poema "O pé do mariñeiro é de natural ancho", con versos de exquisita sensibilidade. A primeira estrofa é un canto ó "pé do mariñeiro", un pé esparrado, aberto (como a sardiña ou o lirio que se laña e adoba para logo fritilos esparrados), con tacto tan sensible que é capaz de distinguir peixes de area moi parecidos como a solla e o trabote -termo propio de Noia que Avilés introduce no galego literario-, á vez que fai de sonda para coñece-lo estado do mar:

O pé do mariñeiro é de natural ancho esparrado nos dedos, afeito a apousentar a sua planta polo mol da area. O tacto tan sensível que coñece cando pisa na solla, no pelouro, no argazo, no trabote. É unha sonda a transmitir o estado do mar: Temperaturas, fluxos, escamallos. Barómetro do tempo. Sinal de fartura de peixe, ou de se houber mar de fondo máis afora da ria.

O pé do mariñeiro é outro cantar... (...)

Meses despois da morte de Avilés editouse Última fuxida a Harar (A Coruña, Espiral Maior,1992), poemario subtitulado Derrota e singraduras, dous termos mariñeiros relativos á navegación, con que se quere "proxectar cara o lector dúas perspectivas fundamentais, premonitorias da vida que remata e que semella abeirarnos cara á revisión dun tempo pasado que o poeta tenta achegarnos a modo de 
diferentes testemuñas de outrora, fieis lembranzas ó lonxe no tempo que se vai extinguindo" (Arxóns Álvarez /Castro Rodríguez 2003: 102-103).

O único poema de Última fuxida a Harar realmente con mar é "Barcos no pór do sol", con léxico mariñeiro popular (motora, mascato, vela, mar, océano, barcos) e léxico culto (leme, trirreme, fragata, nau, derrota). No poema "Meu capitán, é hora, é hora", hai termos relacionados co barco (fanal, pañol, proa, popa) e coa navegación (astrolábios) na primeira estrofa, e tamén na derradeira das estrofas (rumbo, brétemas e o capitán que xa figuraba no comezo do poema).

Moito do léxico do mar de Avilés documéntase en Sarmiento (argazo, barco, navío, rumbos, lañada), en Pintos (barca, cón, marea, maré e beiramar, pouco usada por Avilés que prefire a popular beira do mar de Rosalía), en obras de finais do séc. XIX (calafate, veleiro, goleta, badía, furna, ardentía, cabrestante) ou en Manuel Antonio (gavieiro, leme, roteiro, velamio, cais). Termos de Avilés como galipote, flamexar (a vela), calafatear, astrolabio ou esparrado tiñan moi escasa documentación no galego literario, e outros como (nave) arborizada e trabote (peixe) non tiñan documentación na Base-ILG, ó igual que xarada 'bandada de aves' (Fernández Rei 2003b: 147-148).

\section{A sisga e a conserva de Luísa Castro}

No poemario Baleas e baleas (Ferrol, Esquío, 1988) de Luisa Castro (Foz 1966) danse dúas visións complementarias da Galicia do mar, "a masculina, obrigada á procura do peixe, a achegarse a Irlanda" e "outra feminina, a das mulleres da conserva, dobremente alienadas, explotadas no traballo e utilizadas na casa" (Vilavedra 2000: 55-56).

A sección primeira "Derradeira viaxe en bicicleta de Nevermore" é Irlanda e a pesca no seu mar, xa desde o poema inicial que reproduzo parcialmente:

Todo me dá voltas.

Irlanda está lonxe coma ti, equidistantes

do meu corazón que non vos ama.

Na neveira do barco entre xulianas, esquencido

no pau macho

o meu corazón cóntase entre os animais

máis lentos do bosque.

\section{(...)}

De lonxe

nin Irlanda nin ti:

o meu estómago non vos ama. Amañece con sisgas

e iso é todo.

E rápido pero cobarde. 
Nesta sección inicial hai moito léxico común entre a xente do mar, ás veces rexístrase o castelanismo habitual na fala mariñeira. Son termos referidos ás partes do barco (neveira, puente, cabestrante), ó armador e ós reponsables da pesca (contramaestre, patrón de pesca); ós peixes (xulianas, robalizas, calamares, fanecas salvaxes, meigas, peixes sapo, peixe espada), ó material para pescar (anzois, poteras, palangres) e accións (learse o palangre). Tamén hai algún termo propio de Foz, que non figuraba na Base-ILG, como sisga ("Amañece con sisgas") no poema inicial.

Na sección segunda "Os ventos das baleas" hai algunha voz literaria (rochas, barcas) e nomes populares de animais mariños (polbos, peixe espada, baleas, cachalotes), voces referidas ó barco (cuberta, amarran) e outras como praia, bucear, lobo de mar ou lata de sardiña.

No primeiro dos "Sete poemas sobre leóns" da sección terceira do libro está presente o home no Grande Sole ("meu pai pescando peixe espada/ nas costas irlandesas, nas xeadas augas onde meus abós/ tiñan novísimas amantes") e no poema II aparece a muller e a fábrica de conservas, con léxico tan común como sardiña en lata, mexilóns, cunchas ou caixas de peixe:

Miña nai traballa nunha fábrica de conservas.

Un día miña nai díxome:

o amor é unha sardiña en lata. ¿Ti sabes

como se preparan as conservas

en lata?

Un día miña nai díxome: o amor é unha obra de arte

en lata.

Filla

¿Sabes de ondes vés? Vés

dun viveiro de mexilóns

en lata. Detrás da fábrica, onde podrecen

as cunchas

e as caixas de peixe. Un fedor imposible, un azul

que non vale. De alí vés.

(...)

\section{A planadoira e a traca de Xesús Franco}

O poemario Contra Mar (Vigo, Galaxia, 1995) de Xesús Franco (Vigo 1943) é todo mar, xa desde a páxina inicial inzada de citas de escritores galegos con mar,

29 Segundo me informou Paco Rivas a sisga é un chicote delgadiño, que na punta leva un plomo protexido, que se pon na punta do cabo de amarre. A sisga lánzase ó peirao cando se vai atracar ou ben en alta mar cando se quere dar amarre a outro barco. 
desde a Idade Media ("Treides comigo a lo MAR levado. Martin Codax") á actualidade ("A patria de todos nós: o MAR. Víctor F. Freixanes"). Escrito a partir das vivencias do autor, que foi mariño, presenta un mar enigmático e tráxico, un mar que "non é nada/ nin sequera un eco/ un nome inventado/ oco sen materia". O libro, como se di na lapela, é "un canto á irmandade silenciosa dos afogados".

Na navegación por ese mar Franco válese de voces literarias de Manuel Antonio (recalada, mastro, ronseis, meridianos, rosa dos ventos, singradura), de Avilés e doutros poetas (áncora, derrota), de Cabanillas (rochedos) ou de Ferrín (gobernalle) e de anglicismos para tipos de barcos (bulk carrier, cutter). Tamén emprega formas populares de pouco uso literario (o fumazo de Bernardino Graña, a ceavoga de Xohana Torres) e termos moi cultos sen tradición literaria como alidada (regra para determinar alteracións) ou a ortodrómica referida á rota ortodrómica que é o camiño máis curto dunha parte a outra da superficie terrestre. Tampouco tiña uso literario a hoxe tan popular planadoira ("a planadoira aboia os fardos de winston/ co cantil do Agoeiro"), que tanto axudou na recollida do piche do Prestige cando estaba na boca das Rías Baixas.

No poema "Poetas" aparecen embarcacións tradicionais da pesca de baixura e tamén moi diversos veleiros. Son termos populares ou cultos con diversa tradición literaria:

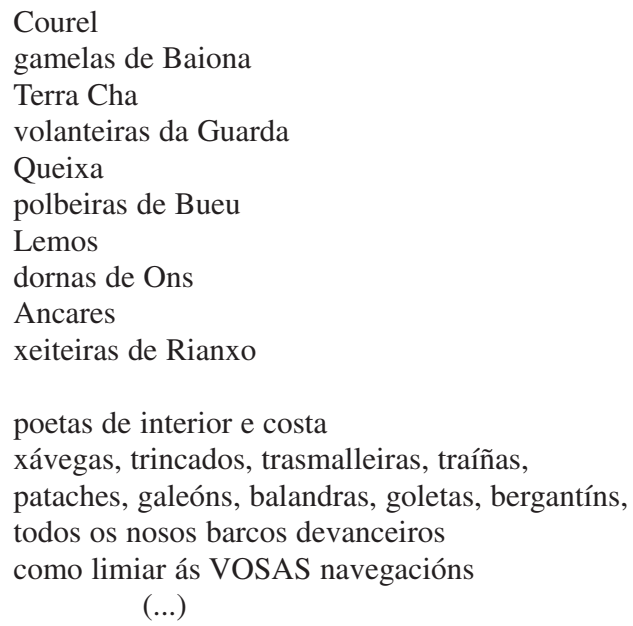

No poema "Vagras, varengas, palmexares" rexístrase léxico moi diverso relativo a partes do barco, sen tradición literaria (vaos, mamparo, bularcamas, buzardas) ou con moi escasa documentación na Base-ILG: 


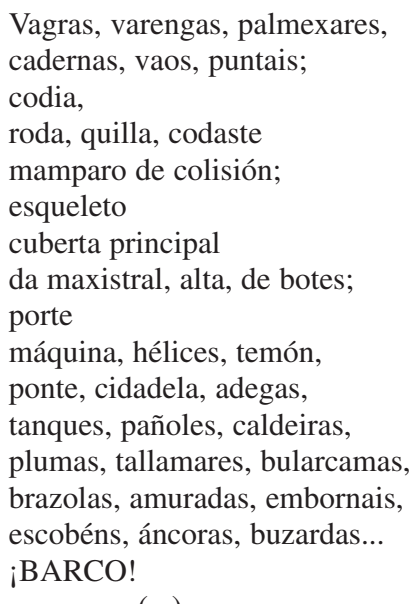

O termo escobén xa se rexistraba na poesía de Zapata García, mentres que codaste, vao e varengas aparecían en textos non literarios de Ríos Panisse (1974) e Mörling (1989), e codaste xa o usara Xaquín Lorenzo na parte etnográfíca da Historia de Galiza (1962).

Noutros poemas Franco usa formas con moi escaso uso literario, como amurada de Paz-Andrade de 1968 (Xan de Masma usara murada en 1899); serviola, peza da proa do barco, que en Freixanes e Alcalá aparece referida ós tripulantes; e resón, a repetición do son pola reflexión das ondas sonoras, que usaran Gayoso Frías e Manuel Rivas. E introduce no galego escrito formas como traca, a caderna que sobresae e vai unida á obra morta; pantocazo, o golpe que dá o barco cando o levanta unha vaga de mar e choca coa seguinte; e esteira 'ronsel', que na Base-ILG non tiña rexistro relativo ó mar.

\section{O mascato e o GPS do barco de pedra de Chus Pato}

O poemario Fascinio (Muros, Toxosoutos, 1995) de Chus Pato (Ourense 1955) é o que máis mar presenta en toda a súa obra publicada. Hai léxico culto e popular de moito uso literario, pero tamén voces da xente do mar de Muros, aprendidos nos anos que traballou nesta vila, e termos cultos que teñen en Fascinio unha das primeiras documentacións no galego escrito.

No primeiro poema “....as mulleres continúan logo de facer as correspondentes estivadas" do libro hai termos populares referidos á pesca da sardiña como ardora, malla e $x a ́ b e g a^{30}$; á estación en que se colle (ceifa), ó tradicional xeito de encascar

${ }^{30}$ Na Base-ILG só se documentaba en Xosé M. Beiras ( $O$ atraso económico de Galicia 1972). 
aparellos de fío cocendo casca de piñeiro e ó traballo da muller na conserva do peixe (estivadas) e no encascado. Tamén hai termos cultos, como a fragata de Manuel Antonio, a furna e a sirte de Pondal. E o vento, tan mariñeiro, abanea unha australia, forma popular de Muros para o eucalipto:

...as mulleres continúan logo de facer as correspondentes estivadas, carrexando leña para encher as pías

a baixar do monte toradas de piñeiro

contribuíndo co seu traballo ás tarefas da xábega

os rapaces maioritariamente descalzos, coas cabezas rasuradas e na súa totalidade presentan sinal de desnutrición...

...dando por perdidos os suministros iníciase a busca da fragata co fin de obter un novo cargamento de armas e municións...

(...)

esa australia abaneada polo vento que me entolece nas bermas do soño (...)

ardora

celestes son as augas

ferve

riza

malla

ceifa

furna

GALLAECIA

iii ubérrima de estrelas!!!

sirte

\section{(...)}

No poema "Poder decir", para Antón Avilés de Taramancos, hai nordés (referido á avea) e océano e formas populares de Avilés (calafates, galipotes, zoco mariñeiro) e as literarias cadernas de Avilés (os populares madeiros e cuadernas), mentres que no poema "Desdeñosos, cisnes, como icebergs", para Xosé Luís Méndez Ferrín hai voces literarias (naus, maré, cetáceos, Gulf-Stream, sirtes, rompentes) e algunhas populares (barcos, peixes, correntes, rede).

No poema "Apodrecen os mortos na encrucillada da semente", a chegada do outono márcase coa voz valume ${ }^{31}$, as algas que foron podrecendo coa calor do verán, que

31 No poema "Neno da beira do mar" de Un tempo de sol a sol (1974) de Lueiro Rey, entre outro léxico do Grove onde o poeta vivía, está balumada ("Lavouche o mar os ollos con salitre/ púxoche o mar, no peito, valumada"), a broza que arría o mar, que corresponde co balume de Sarmiento e co esterco de portos arousáns como Cambados, Carril e Ribeira. En Pondal (1995: 114, 274) rexístrase valume ("Cal soe arboradura/ de nave poderosa/ facer negro valume/ sobre as tendidas olas"), se cadra co mesmo valor. 
aboian nos días de calmiña borrada de agosto e que indican o cambio de estación, igual cás grandes mareas vivas equinocciais de comezos de marzo e setembro.

Nas augas mariñas da comentada cantiga moral "Non me posso pagar tanto" de Afonso X había un galeón e un dormón, mentres que nas augas de "Na obsesión por balbucir palabras" navegan a goleta de Manuel Antonio e o dormón de Afonso $\mathrm{X}$, forma que na Base-ILG non estaba documentada.

O poema "O buque non está no altar", homenaxe a Manuel Antonio, ten no comezo termos modernos relativos á propulsión do buque (a popularizada hélice e a culta inxección ${ }^{32}$ ) e voces cultas incorporadas á fala, como radar e sonda, ex-votos cos que se prevén un perigo ou se mide a profundidade do mar:

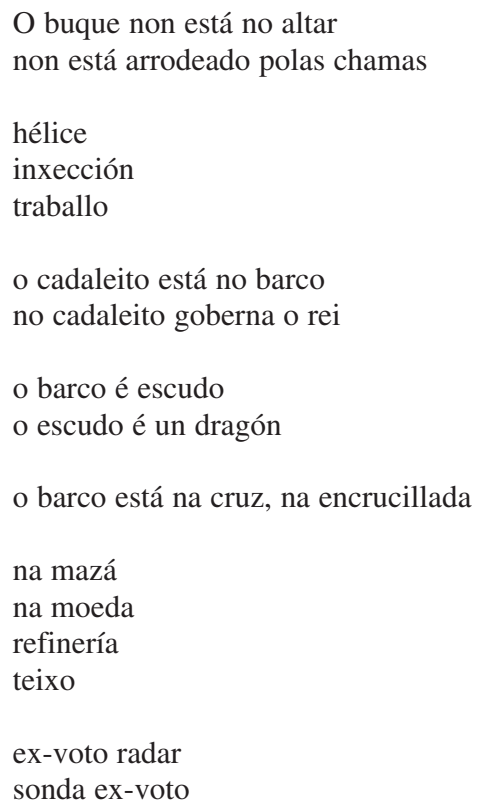

Aínda que se trata dun barco de pedra, como calquera barco, ten motor e ponte, onde vai o barqueiro, ten partes como codaste e amuras e para navegar válese da cofa (ou gabia). E para a detección do peixe o barco de pedra conta cun método tan tradicional como a observación do voo do mascato; pero ese barco de pedra tamén conta coas máis modernas innovacións, como o GPS, sistema por satélite para a localización do banco de peixe (a barría ou cardume). O mascato era unha ave

32 Na Base-ILG a única documentación desta forma estaba nunha obra non literaria, Prácticas de mecánica (1992), de D. Castro Picos, X. P. González Moreira e X. Lagilde Edros. 
mariña moi apreciada polos mariñeiros que traballaban de día ó caldeo da raba, porque ó tirarse á auga era sinal de que alí había sardiña ou outro peixe. En Manuel Antonio hai algún mascato pousado "n-a cruz d'un navegante", e o barco de pedra de Chus Pato "está na cruz, na encrucillada".

O barqueiro ten o sol e as estrelas para se orientar, mais tamén se vale do moderno sextante do pailebote de Manoel Antonio e das singraduras poéticas de CastilloElejabeytia, Darío X. Cabana e Ferrín ${ }^{33}$, e conta coa moderna agulla náutica de Paz-Andrade $^{34}$ e coa máis moderna aínda (agulla) xiroscópica ${ }^{35}$ :

no mascato
Deka
GPS
Loran
Wärstila
Diesel
O barqueiro baila o sol
baila a estrela
ten sextante
agulla náutica
xiroscópica
ten esposa
ten patrón
-mirando negro
negrura sempre
$\quad(. .$.

E contra o final deste poema a Manuel Antonio, a vida do mar represéntase co nome latino dunha alga (a "Laminaria Hiperborea") e co cultismo plancton.

O poema "Néboa", con léxico popular da beiramar, en certo modo é unha homenaxe á muller da costa: á reghateira que vende o lote de peixe que leva na motora e á que ata as redes (muller-redeira), á que anda á fábrica (muller-conserva) e a que

33 A forma sextante introduciuna Manuel Antonio en De catro a catro (1928). As seguintes documentacións da Base-ILG están na prosa de Víctor Freixanes (O triángulo inscrito na circunferencia 1982) e na poesía de Dictinio del Castillo-Elejabeytia (O espello das brétemas 1987), Darío Xohán Cabana (Patria do mar 1989) e Méndez Ferrín (Estirpe 1994).

${ }^{34}$ As únicas documentacións de agulla náutica na Base-ILG eran de V. Paz-Andrade (Sementeira de vento 1968) e de Eduardo Soto Álvarez e José Suárez Costa (Competencia de mariñeiro 1990). Nesta obra e no prólogo da Escola de menciñeiros de Cunqueiro (1960) de García Sabell rexístrase agulla náutica, mentres que ag(h)ulla de marear ten diversas documentacións xa desde finais do séc. XIX.

35 As únicas documentacións deste aparello electromagnético estaban nunha obra non literaria, Competencia de mariñeiro (1990) de E. Soto Álvarez e J. Suárez Costa. 
anda á seca (muller-ameixa), á muller-quiñón, á muller-cooperativa.... Noutros poemas hai formas con moi escasa documentación, por seren termos modernos, como o ferry de Neira Vilas ${ }^{36}$ ou a doca de Ferrín ${ }^{37}$.

O poema que fecha Fascinio só ten dous versos ("As Cocas de Marzo/ os Equinocios"), que se refiren ás grandes mareas vivas equinocciais, cocas para a xente de Muros, forma que introduce Chus Pato no galego literario ${ }^{38}$.

\section{As últimas mareas léxicas na poesía}

Nos anos 90 e nos comezos do séc. XXI editáronse diversos poemarios con salitre e mar, que paso a enumerar, con indicacións moi xerais sobre o léxico de mar que conteñen. En diversas calas apreciei que, xunto a léxico maioritariamente literario, nestas últimas mareas tamén hai formas que non estaban documentadas na BaseILG.

Rafael Lema (Ponte do Porto-Camariñas 1967) é autor do poemario Cemiterio das gaivotas (A Coruña, Espiral Maior, 1993), cinco viaxes mariñas con diversas singraduras. Usa formas literarias como rotas, ronseis, mastros, veleiro ou golfiño e formas populares como estela ("Volves ó mar, desanda-la estela coñecida), saín, gamela, chalana ("bogas chalana de soños"), rizón $n^{39}$ e ciabogar ${ }^{40}$. Nos poemas de amor de $O$ devalo do mar (Santiago de Compostela, autoedición, 1994) de Rafa Villar (Cee 1968) o vocabulario é, en xeral, moi literario (maré, naus, ondas, rotas, ronseis, leme e velame), pero tamén con voces populares xa literarias (furna, buguinas).

Ana Romaní (Noia 1962) publicou Das últimas mareas (A Coruña, Espiral Maior, 1994) e Arden (A Coruña, Espiral Maior,1998). Neste poemario o léxico mariñeiro son baleas e cachalotes, algún océano e algunha illa e varias gamelas, con tradición no galego escrito, ou ben termos de moi escasa tradición como crebas ("que

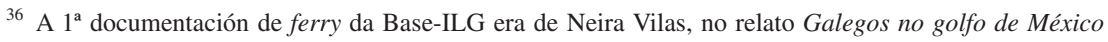

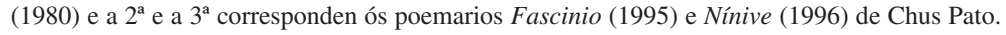

37 A única documentación da doca mariña da Base-ILG estaba na prosa de Bretaña Esmeraldina (1987), de Méndez Ferrín ("polas partes areosas de Rennes ou polas docas de Saint-Malo").

${ }^{38} \mathrm{Na}$ fala mariñeira do Porto do Son e de Ribeira a forma equinosio designa un temporal moi forte que pode darse canda as mareas equinociais no comezo da primavera e do outono, as "Cocas de Marzo" de Chus Pato e as lagarteiras de setembro de Rosa Aneiros, tan areladas polos percebeiros de Valdoviño.

39 Nunca usa a literaria áncora; pero en casos como "Fondo rizón de babor (cinco grilóns)" (p. 18) o uso de rizón é moi chocante, porque este amárrase cun cabo e é a áncora é a que leva elos ou grillóns.

${ }^{40}$ Zapata García usara cían e vogan en A roseira da soidade. Máis documentado está o substantivo: ciavogas en Sementeira do vento (1968) de Paz-Andrade, ceavoga en Adiós, María (1971) de Xohana Torres e ceavogas en Contra Mar (1995) de Xesús Franco. 
sexan eses corpos os rastros que debulle/ cada tarde nas crebas"). Usa a forma chapapote de Noia (e de portos coruñeses como O Pindo, Oleiros ou Cariño ${ }^{41}$ e en zonas da Galicia interior) o que é piche nas Rías Baixas (e en Carnota) e galipote en moitos portos da Costa da Morte e da Mariña de Lugo.

Paco Rivas (Cervo 1955) é autor de Cantaruxos do meu mar e outras cantigas (Santiago de Compostela, Follas Novas, 1999) polos que zoa "o aire da Mariña toda", con algún poema mareiro como o do portiño de Nois en Foz ("xa todos van en Burela/ quedaches orfo de lanchas/ orfas quedaron as penas"). Entre os escasos termos mariños hainos literarios (ondas, remar) e populares de uso xeral (vogar, lancha) ou propios da Mariña e doutras zonas (redeira, penas, que corresponde a atadora e cons de Cambados ou Ribeira). Tamén presenta algún termo característico dos mariñaos de Foz, como pariñeira 'cantil' e aruxo, que non se documentaban na Base-ILG, e xogaral con documentación moi recente ${ }^{42}$.

En Hinterland (Santiago de Compostela, Positivas, 1999) de Pilar Beiro (San Mamede-Carnota 1958) hai unha gran riqueza de léxico mariñeiro, unhas veces común (argazo, lañar, míllaras), outras veces literario (áncora, pailebote). Nalgún caso trátase de léxico da Costa da Morte xa introducido (crebas) ou sen documentación no galego literario como memelo, voz para un tipo de argazo en Lira-Carnota e O Sardiñeiro-Fisterra, ou mexilla, a cría do mexillón ${ }^{43}$.

No poemario Nas varandas do abrente (Viveiro, 2000) de Xoán Neira (MeilánLugo 1953) está a ría e o mar de Viveiro e as illas da Mariña occidental con "baleas ancoradas, pousadas nas ondas/ referencias do paso dos trebóns/ que avanzan na noite do nordés"). O léxico mariñeiro é común (ría, nordés) e literario (ancorados, ronseis e moitas ondas).

${ }^{41}$ Segundo me informa Xabier Cordal, ata hai anos a forma chapapote era considerada en Cariño como pouco de mar. Era o termo da xente da 'vila' (Ortigueira), cando Cariño aínda non era concello, pois a forma popular da xente de mar era floiz/floid. Despois da marea negra do Prestige posiblemente a xente de mar use con naturalidade a forma chapapote. Isto é o que apreciei en mariñeiros de Cambados, que sempre dixeron piche e que despois de estaren varios días na boca da ría da Arousa, e mesmo na costa, recollendo o que os media chamaban chapapote, agora xa usan este termo.

${ }^{42}$ Nun Diccionario fraseolóxico do mar (inédito) Paco Rivas define aruxo como "calquera cousa pequena, moi molesta, que se mete nos ollos. En termos mariñeiros, utilízase para indicar que o mar comeza a poñerse malo", mentres que xogaral é "lugar onde o mar vai xuntando coios pulidos pola erosión". Na Base-ILG a 1 ${ }^{a}$ documentación de xogaral está en Bidueiras d'inverno (1990), do eo-naviego Xosé Miguel Suárez, mentres que aruxo non presentaba documentación.

43 A voz mexilla a comezos do 2003 estivo moi presente nos medios de comunicación, tanto en información en galego como en español, polo conflicto entre os bateeiros e os percebeiros, por estes non poderen traballar nos cons da Costa da Morte cheos do galipote do Prestige, mentres que si se permitía coller mexilla ós bateeiros nesa costa onde cada ano arrincan unhas $7.500 \mathrm{tm}$ desa cría, fundamentalmente da zona que vai de Muros a Muxía. 
Miro Villar (Cee 1965) publicou Gameleiros, mar de rostros (Vigo, Xerais, 2002), con fotos de Manuel Álvarez de 27 gameleiros da Guarda, "que laboran ó día coas diferentes artes tradicionais de pesca herdadas dos seus antepasados, nun espacio de mar que vai dende a desembocadura do río Miño ata a latitude do mosteiro cisterciense de Santa María de Oia”. Nos 27 quintetos para eses rostros gameleiros hai léxico do mariñeiro que anda á pesca de baixura (ardora, largar aparellos), do mariñeiro-gladiador "que pelexa en circos de argazo", do percebeiro "corpo neoprano e brazos cordas" (rasqueta), do que traballa con "brazolada de tanza" e doutros gameleiros que soportan suradas. E hai formas populares con escasa tradición literaria (a comentada ceavoga) e formas moi literarias que non son populares, como as xerfas do poemario De catro a catro (1928) de Manuel Antonio, que Dieste usou por primeira vez nun texto en prosa de 1926.

O pintor e poeta arousán Xurxo Alonso, nado en Buenos Aires (1956), mais residente en Vilagarcía, é autor de Onde viven os saqueadores de naufraxios (A Coruña, Espiral Maior, 2002), con vocabulario moi literario (gaivotas, rochas e badías; buques, naves, navíos e mascaróns de proa); mais tamén con algunhas formas case inexistentes no galego escrito, como batume (alga) e pecio (restos dun barco afundido) $)^{44}$.

A forma pecio, de tanta presencia nos media a comezos do 2003 cando o comité científico do Prestige se refería ó petroleiro, e que a prensa escrita acabou usando tamén, está no poemario Alma mareira (Pontevedra, Diputación Provincial, 2003) de Luís Rei Núñez (A Coruña 1958), con raíces familiares en Santiago de TalMuros, de onde toma formas como mareáns para ondas (ou tombos), que el introduce no galego escrito ou borraxeira para a néboa que se forma sobre o mar, voz que introducira López Abente en 1929. Luís Rei usa formas pouco documentadas como calabrote (cabo groso) ou colla 'cuadrilla de estibadores'.

\section{A gran marea no mar escoso de Alexandre Nerium}

Alexandre Nerium, nome literario de Manolo López Martínez (Fisterra 1960) gañou o VII Premio de Poesía Johán Carballeira do ano 2002 (ex-aequo con Carlos Negro) co poemario Vogar de couse (de inminente publicación). Hai tal enxurrada de mar e de léxico mariñeiro fisterrán e "técnico", que esta obra supón unha modernización do vocabulario do mar dalgún xeito semellante á que se produciu con $D e$ catro a catro de Manuel Antonio e con Profecía do mar de Bernardino Graña.

\footnotetext{
44 A forma pecio, que o castelán tomou do gascón ant. pessi (de nau), defíneo o diccionario da RAE como "pedazo o fragmento de la nave que ha naufragado o porción de lo que ella contiene. // Derechos que el señor del puerto de mar exigía de las naves que naufragaban en sus marinas y costas". A única documentación na Base-ILG está en A Nosa Terra (1993), onde pecios aparece coa aclaración de "restos de barcos afundidos".
} 
O mariñeiro-poeta de Fisterra emprega moito léxico mariñeiro relativo ás partes do barco (palmexar, cairel, embornais, trancanís, pantoque, vagra, tallamar, estrave, turafaia), á vela e ós mastros (artemón, bauprés, carlinga, relingar). Algúns destes termos (artemón, estrave e turafaia) non están documentados na Base-ILG, mentres que outros teñen presencia no galego literario, como bauprés da poesía de Zapata, Celso Emilio, Avilés, Castillo, Chus Pato e Tabuyo e máis da prosa de Freixanes, Caneiro e Alcalá; cairel en Cotarelo e Paulino Vázquez; carlinga en Cotarelo, Braxe e Abella; embornal en Zapata, P. Vázquez e Ferrín, relingar en Dieste, palmexar e vagra en Xesús Franco e tallamar en Alcalá. Algúns termos só se documentan en obras recentes non literarias, como trancanil ou pantoque (Fernández Rei 2003a).

Verbo da acción dos vagallóns sobre o barco Nerium usa os cultismos arrufo e quebranto $^{45}$ e léxico patrimonial relativo ó mar de uso xeral como baixos e ardentía, cabesos e petóns, xunto con termos da xente da Costa da Morte tombos, coídos ou fisgas, que xa usara Zapata García. Outras moitas formas non se documentan na Base-ILG, fóra dalgún termo animal sobre todo, ou ben non teñen o sabor a salitre. É o caso de formas fisterrás como ferretes e arnela (praia pequena en Fisterra) que alternan cos "literarios" farallóns e praia, así como voces relacionadas co mar de vento (rutías, maraxe, axada) e co vento que sopra con moita forza (xaramiño, fogada), co relevo mariño (petón, pedra visible cando baixa a marea), con moluscos (peneira, pé de muño) e con aves (curricacho, pardela), co argazo (blandón, cachopa) e con accións como esparar para se referir á abertura da rede ou apariguar para o feito de as pezas das artes de deriva poñérense unhas ó par das outras (Fernández Rei 2003a).

Os cinco quintetos do poema que fecha Vogar de couse, as "Verbas para un mar escoso", voces para un mar que non o tocou ninguén, en que hai abundancia de peixe e se pode facer unha boa marea, é unha homenaxe ó mar e á terra e ós poetas que cantaron a terra (Manuel María, Novoneyra) e o mar (Bernardino, Ferrín, Xohana Torres).

E remato as miñas singraduras polos mares da poesía galega, de onte e de hoxe. Aplicar un "bisturí lexicográfico" en poemarios onde hai concentrada tanta beleza, tratando de buscar primeiras documentacións e examinando se os termos usados son populares ou cultos, se son da tradición literaria ou innovacións, se a súa

45 Formas moi técnicas que non se documentan nos textos literarios da Base-ILG na acepción náutica, pero que usara Mörling (1989) na monografía das embarcacións tradicionais galegas. O arrufo e o quebranto saltaron á prensa galega en novembro do 2002 cando naufragou o Prestige, cando pouco antes do seu afundimento se trataba de explica-lo por que do accidente. O petroleiro puido sufrir un arrufo, fenómeno que fai que unha onda levante a proa e outra a popa, polo que queda o centro do barco no aire; ou ben o accidente puido deberse a un quebranto, isto é, que una onda levantase o barco polo centro co que a proa e a popa quedarían no aire. En ámbolos casos, o casco pode partir, como ocorreu co Prestige. 
semántica é galega, e mesmo indagar na súa posible fonte, seguro que a algúns, especialmente a algún autor, lle pode parecer un atentado á beleza do texto.

Esa "carnicería", por usar un termo de Santamarina, que os filólogos facemos nos textos literarios, e en particular a detallada "carnicería" que realicei hai uns anos na poesía de Cabanillas e Manuel Antonio (Fernández Rei 1999) e a menos detallada en poetas analizados neste traballo, creo que é necesaria, e mesmo urxente, para tratar de coñecer mellor a lingua dos clásicos que, unha vez peneirada, ten que ser introducida nos diccionarios para que estea mellor representada a lingua literaria que, non obstante, ten xa bastante presencia. Algún día todo o vocabulario dun poeta como Manuel Antonio deberá estar nos diccionarios de uso, porque é moita a transcendencia que tivo, e que segue a ter, este renovador da poesía e modernizador da común patria da lingua.

\section{Referencias biliográficas}

Alvar, M. (1985): Léxico de los marineros peninsulares, 2 (Madrid: Arco / Libros).

Arxóns Álvarez, Ma D./ Castro Rodríguez, X. (2003): Antón Avilés de Taramancos. Vida e obra (Vigo: Xerais).

Barriuso Fernández, E. (2002): Atlas léxico marinero de Asturias ([Oviedo]: Real Instituto de Estudios Asturianos).

Blanco, C. (1998): “Amar no mar”, en Gay Parga, T. (ed.), Ondas do mar de amigo: 8184 (Lugo: Citania).

Bouza Brey-Trillo, F. (1980): Obra literaria completa (Santiago: Cerne).

Brea, M. (coord.) (1996): Lírica profana galego-portuguesa. Corpus completo das cantigas medievais, con estudo biográfico, análise retórica e bibliografía específi$c a, 2$ vols. (Santiago de Compostela: Centro de Investigacións Lingüísticas e Literarias Ramón Piñeiro).

Cabanillas, R. (1959): Obra completa (Buenos Aires: Galicia).

Capelán, A.(1996): "Un autor nunca esquecido. Da frustrada homenaxe de 1936 á de 1960", en Manuel Antonio. Embarcados nun cantar. Extra de A Nosa Terra: 2546 (Vigo: A Nosa Terra).

Capelán, A. (2002): “Os soños comprometidos dun poeta épico", en Acuña, X. E./ Sánchez Iglesias, C.: Antón Avilés de Taramancos. A nosa cultura 21: 16-31 (Vigo: A Nosa Terra).

Carballo Calero, R. (1981) [1963]: Historia da literatura galega contemporánea 18081936 (Vigo: Galaxia). 
Cotarelo Valledor, A. (1970): "La poesía del mar en el 'Cancionero de la Vaticana', Grial, 30: 463-77.

Cunqueiro, A. (1991): Obra en galego completa. Poesía. Teatro I (Vigo: Galaxia).

Fernández Naval, X. (1999): O mundo da pesca na literatura galega. (Oleiros: Centro de Documentación Domingo Quiroga, Casa da Xuventude-Concello de Oleiros).

Fernández Rei, F. (1999): Ramón Cabanillas, Manuel Antonio e o Mar da Arousa. Dúas singraduras na construcción dun idioma para unha patria (A Coruña: Real Academia Galega).

Fernández Rei, F. (2000): “O mar na obra literaria de Ramón Cabanillas”, Ponte Norga. Revista de estudios sociolingüísticos, 2: 77-104.

Fernández Rei, F. (2001): "O mar na literatura galega: ondas, ventos, illas, ribeiras e vagallóns”, en Pérez Alberti, A. (coord.): Galicia fai dous mil anos. O feito diferencial galego. IV. As paisaxes de Galicia: 219-260 (Santiago de Compostela: Museo do Pobo Galego).

Fernández Rei, F. (2003a): “Moita costa, 'pouco mar': o léxico mariñeiro e a construcción do estándar galego". Conferencia no Simposio "Léxico e Estandarización en Galicia” (Santiago de Compostela, outubro-novembro 2002) (no prelo).

Fernández Rei, F. (2003b). "Noso é o remo e o adival. Mar e léxico do mar en Avilés de Taramancos", en Avilés de Taramancos. Día das Letras Galegas, 2003: 125149 (Santiago de Compostela: Universidade).

Filgueira Valverde, F. (1927): A paisaxe no Cancioneiro da Vaticana (A Cruña: Lar).

Graña, B. (1966): Profecía do mar (Vigo: Galaxia).

Graña, B. (1995): Ardentía (Obra poética completa) (A Coruña: Espiral Maior).

Guerra da Cal, E. (1958): "Glosas superficiaes ao tema do mar da nosa lírica primitiva", en Homaxe a Ramón Otero Pedrayo no LXX aniversario do seu nacimento: 145-171 (Vigo: Galaxia).

Lapa, M. Rodrigues (1970): Cantigas d'escarnho e de mal dizer (Vigo: Galaxia).

Leiras Pulpeiro, M. 1970: Obra completa. Estudo crítico de X. L. Franco Grande (Vigo: Galaxia).

Leiro Lois, A. (1990): O traballo no mar (Aparellos e artes de pesca e marisqueo) (Cambados: Colexio Público Castrelo-Cambados).

Manuel Antonio (1992): Poesía galega completa. Ed. de Xosé Luís Axeitos. (Santiago de Compostela: Sotelo Blanco). 
Mörling, S.(1989): As embarcacións tradicionais de Galicia ([Santiago de Compostela]: Consellería de Pesca).

Pena, X. R. (1996): Manuel Antonio e a vangarda (Santiago de Compostela: Sotelo Blanco).

Pondal, E. (1995): Poesía galega completa. I. Queixumes dos pinos. Ed. de Manuel Ferreiro (Santiago de Compostela: Sotelo Blanco).

Pondal, E. (2002): Poesía galega completa III Poemas manuscritos. Ed. de Manuel Ferreiro (Santiago de Compostela: Sotelo Blanco).

Ríos Panisse, Ma C. (1974): "Vida mariñeira de Sada. Contribución para un estudio lingüístico", Verba, 1: 181-232.

Ríos Panisse, $M^{\text {a }}$ C. (1983): Nomenclatura de la flora y fauna marítimas de Galicia. II. Mamíferos, aves y algas. Anexo 19 de Verba (Santiago de Compostela: Universidade).

Santamarina, A. (ed.) (2001) [2000]: Diccionario de diccionarios. Versión 2 (A Coruña: Fundación "Pedro Barrié de la Maza, Conde de Fenosa").

Sarmiento, Fr. M. (1970): Colección de voces y frases gallegas. Edición y estudio por J. L. Pensado (Salamanca: Universidad).

Tavani, G. (1989): “A auga e a poesía galega medieval”, en ...Tódalas augas. Libro-carpeta, sen paxinar, con presentación e selección de dezasete poemas galego-portugueses de autores medievais a cargo de G. Tavani e con serigrafías de M. Montcada (Santiago de Compostela: Xunta de Galicia. Consellería de Cultura e Deportes).

Vilavedra, D. (coord.) (1995): Diccionario da literatura galega. I. Autores (Vigo: Galaxia).

Vilavedra, D. (coord.) (2000): Diccionario da literatura galega. III. Obras (Vigo: Galaxia). 